\title{
Landscape-Scale Disturbance: Insights into the Complexity of Catchment Hydrology in the Mountaintop Removal Mining Region of the Eastern United States
}

\author{
Andrew J. Miller ${ }^{\dagger}$ and Nicolas Zégre ${ }^{*, \dagger}$ \\ School of Natural Resources, West Virginia University, P.O. Box 6125, Morgantown, WV 26506, USA; \\ andrew.ajm@gmail.com \\ * Correspondence: nicolas.zegre@mail.wvu.edu; Tel.: +1-304-293-0049 \\ + These authors contributed equally to this work.
}

Academic Editors: Artemi Cerdà, Saskia Keesstra, Tammo Steenhuis and Paolo Tarolli Received: 3 April 2016; Accepted: 16 June 2016; Published: 5 July 2016

\begin{abstract}
Few land disturbances impact watersheds at the scale and extent of mountaintop removal mining (MTM). This practice removes forests, soils and bedrock to gain access to underground coal that results in likely permanent and wholesale changes that impact catchment hydrology, geochemistry and ecosystem health. MTM is the dominant driver of land cover changes in the central Appalachian Mountains region of the United States, converting forests to mine lands and burying headwater streams. Despite its dominance on the landscape, determining the hydrological impacts of MTM is complicated by underground coal mines that significantly alter groundwater hydrology. To provide insight into how coal mining impacts headwater catchments, we compared the hydrologic responses of an MTM and forested catchment using event rainfall-runoff analysis, modeling and isotopic approaches. Despite similar rainfall characteristics, hydrology in the two catchments differed in significant ways, but both catchments demonstrated threshold-mediated hydrologic behavior that was attributed to transient storage and the release of runoff from underground mines. Results suggest that underground mines are important controls for runoff generation in both obviously disturbed and seemingly undisturbed catchments and interact in uncertain ways with disturbance from MTM. This paper summarizes our results and demonstrates the complexity of catchment hydrology in the MTM region.
\end{abstract}

Keywords: mountaintop removal mining; catchment hydrology; disturbance hydrology; streamflow generation; underground coal mining

\section{Introduction}

Determining the hydrological impacts of an individual disturbance from multiple, overlapping disturbances in space and time is a major unresolved issue for hydrological sciences [1], even when considering landscape-scale disturbances, such as mountaintop removal mining (MTM). MTM is a special form of surface mining adapted to mountain landscapes that removes forests, soils and overlying bedrock to gain access to underground coal seams. This practice leads to likely permanent and wholesale changes to catchment organization, structure, soils and vegetation that have important implications for catchment hydrology, geochemistry and ecosystem health [2-4]. The hydrological impacts of this practice are under increasing scrutiny following several devastating floods (e.g., [5]) and well-established patterns of biological impairment downstream of MTM [4,6,7] that implicate disturbance-driven changes in hydrology. 
Surface mining for coal is the dominant driver of land cover changes $[8,9]$ in the portion of the Appalachian Coalfields region within West Virginia, Kentucky, Virginia and Tennessee, impacting nearly $7 \%$ of the mostly forested 4.86 million hectare area (Figure 1), burying $\sim 4000 \mathrm{~km}$ of headwater streams under valley fills [10]. Despite the scale and extent of its disturbance, impacts from MTM on catchment hydrology are poorly understood. Knowledge gaps are vast and stem primarily from a paucity of pre- $v$ s. post-impact studies due to limited access to private property [6] and the lack of consistent, long-term, scale-appropriate gauged watersheds [2]. The challenges of conducting research in heavily-disturbed and ever-changing environments [11] often prevents process-based and long-term studies, and the challenges of isolating the hydrological impacts of one disturbance within the context of multiple, overlapping disturbances [1] precludes better understanding of the hydrological changes that result from MTM.

While surface mining is the dominant disturbance in the region, nearly two centuries of heavy natural resources extraction (e.g., mining, oil and gas, timber), agriculture and natural disturbances (e.g., fire, disease, insect defoliation) have resulted in a mosaic of land covers, land uses and land forms that complicate regional hydrology and make determining baseline conditions difficult. This region has a long history of underground coal mining with mines underlying much of the region where MTM is prominent (Figure 1). Underground mines pose significant challenges for understanding the hydrological impacts of surface mining [12-14], and most surface mining studies intentionally exclude the confounding effects of underground mining to isolate surface mining impacts on hydrology.

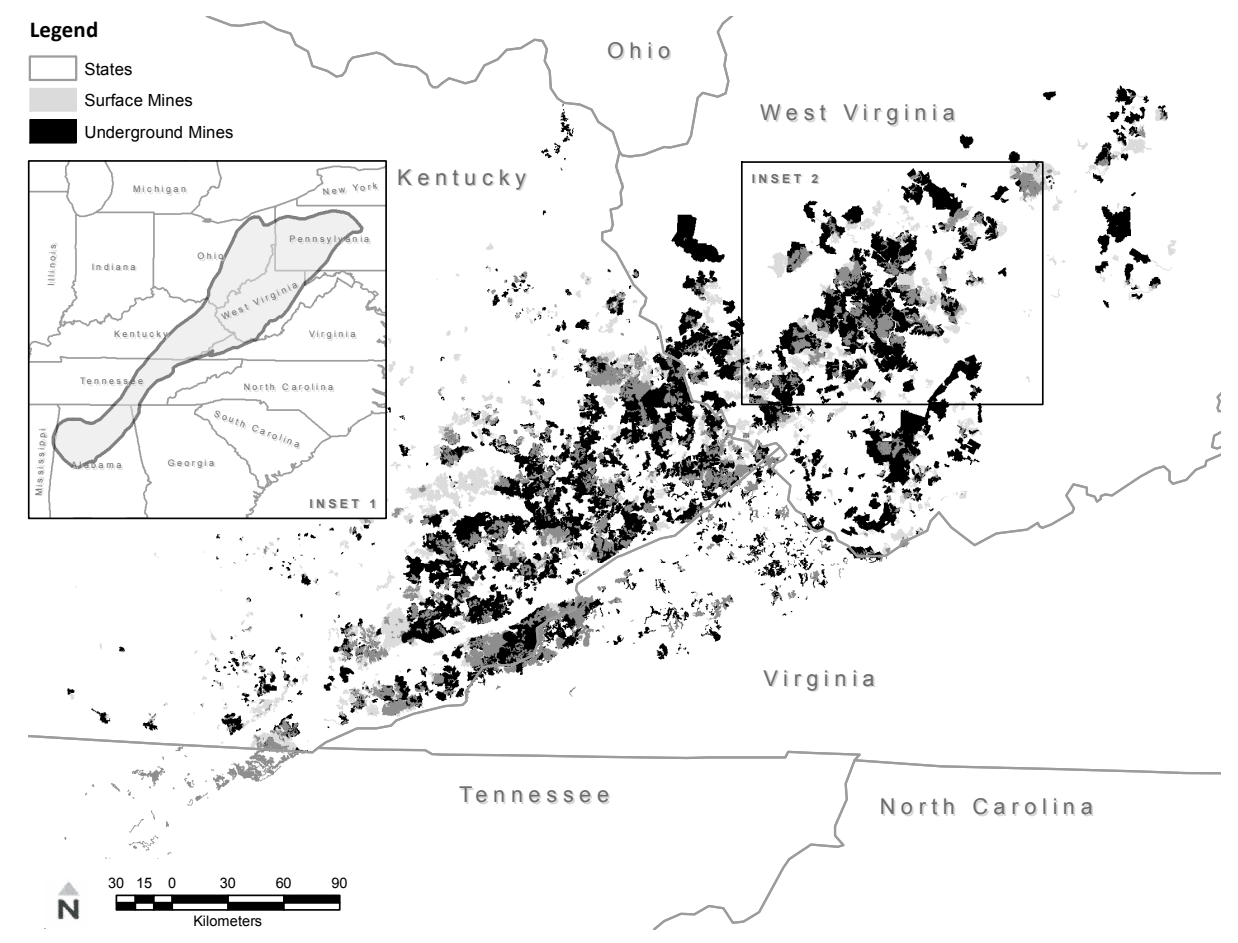

Figure 1. Extent of mountaintop removal mining and underground coal mining in the central Appalachian Mountains region. Surface mines have disturbed nearly $7 \%$ of this predominantly forested 4.86 million hectare region of West Virginia, Kentucky, Virginia and Tennessee, and underground mining has impacted $25 \%$ of the area. Inset 1 : the Appalachian Coalfields region, extending from Pennsylvania to Alabama, has a long history of coal mining. Inset 2: location of the current study.

Given the prominence of underground mining and the overlap of surface and subsurface mining disturbances, it is important to frame MTM impacts within the context of the existing disturbance regime. This is not a trivial task, as isolating the hydrological impacts of one disturbance from multiple, overlapping disturbances is a major unresolved issue in hydrology [1] that is exacerbated by the 
paucity of streamflow, groundwater and underground mine discharge measurements in the MTM region, as well as uncertainty about the actual extents of centuries-old underground mining.

As a starting point for understanding the potential confounding impacts of multiple disturbances on catchment hydrology, this study combined the analysis of local and regional coal geology and mining maps with small catchment hydrologic monitoring to provide insights into how MTM impacts catchment hydrology within the context of the existing disturbance regime. To do this, we quantified the extent of underground mining in the MTM region and below two nearby headwater catchments, one forested and one impacted by MTM, and compared their hydrologic responses using event rainfall and runoff data, modeling and isotopic approaches. This paper summarizes our results from analyzing 23 storm events over a thirteen-month study period and demonstrates the complexity of catchment hydrology in heavily-disturbed landscapes and highlights the challenges for isolating the hydrological impacts of one disturbance from within an existing disturbance regime.

\section{Overview of Coal Mining and Hydrology}

Unlike traditional surface mining practices, such as contour, high wall and strip mining that impact a few hundred hectares, MTM disturbs thousands of hectares [2,15], with the largest MTM occupying $\sim 4000$ hectares $\left(\sim 40 \mathrm{~km}^{2}\right)$ [16]. MTM removes as much as $200 \mathrm{~m}$ of overburden from ridge tops [17] generating large volumes of waste rock that precludes replacing the material back on the ridge. Overburden material is cast into adjacent stream valleys, creating valley fills that completely bury headwater streams. The placement of waste material in headwater valleys forces contact time between runoff and overburden geology. Streams downstream of valley fills are characterized by high $\mathrm{pH}$, conductivity and total dissolved solids due to elevated concentrations of selenium, sulfate, calcium, magnesium and bicarbonate ions $[6,7,10,18,19]$. The wholesale reconfiguration of catchments from surface mining and valley fills certainly impacts important runoff generation controls, such as the flow path gradient [20] and riparian zone contributions [21], but how and to what degree is unknown.

Conceptually, the impacts of surface mining on hydrology are straight forward; the often permanent removal and conversion of forests to exotic grasses [22,23] alters the water balance by reducing evapotranspiration (ET) [24], and the removal of soils and severe soil compaction [25] from heavy machinery use in mining and reclamation activities alters dominant flow paths and catchment storage. Runoff tends to be dominated by infiltration-excess overland flow [26,27], and some studies have found that streamflow downstream of surface mines tends to be flashy with large peak flows and storm flow volumes (e.g., $[14,28,29])$. However, MTM results in a two-part system with contradictory controls on hydrology [2]. Valley fills act like headwater aquifers that temporarily store and release water overtime [30], increasing catchment storage and potentially offsetting runoff increases from impervious surfaces. Streamflow, base flow and flow durations downstream of valley fills are frequently elevated, shifting the hydrologic regime of historically ephemeral headwater streams to perennial [31,32]. The effects of valley fills on storm flows are less well understood; both larger and smaller peak flows have been observed downstream of valley fills [12,23,28]. Differential responses of streamflow to surface mining are primarily due to different mining and reclamation practices, different scales of disturbance [2] and, to an uncertain extent, different disturbance histories.

Our previous work in the MTM region quantified the expansion of MTM in the Big Coal River watershed and the nature of hydrologic impacts across spatial and temporal scales [33,34]. At the basin scale $\left(>10^{3} \mathrm{~km}^{2}\right)$ and over the lifetime of this practice (1969-2012), maximum streamflow and streamflow variability decreased while the base flow ratio increased. At the headwater scale $\left(10^{1} \mathrm{~km}^{2}\right)$, we have found a rapid translation of rainfall to event runoff based on transfer function modeling that showed little variation between response curves, high runoff ratios and small proportions of quickflow for four dormant seasons storms in White Oak Creek (also the focus of the current study). Based on the extensive underground mining, it was uncertain if increasing base flows, decreasing variability and the high runoff ratios were attributed to surface mining and valley fills or from unaccounted for water from underground coal mines that underlie much of the region. 
Groundwater flow in un-mined areas of the Coalfields region is primarily controlled by fractures that formed as a result of erosional stress relief [12]. Underground mining drastically alters the subsurface structure [35] and increases hydrologic connectivity between the surface and subsurface and between water-bearing subsurface geologic units [36,37]. The effects of underground mining on groundwater flow will largely depend on the connection of mines to fracture systems [12] that efficiently connect groundwater to surface streams. At multiple spatial scales, substantial volumes of water can be transferred between basins and between the subsurface and surface that can diminish, obfuscate or exacerbate surface mining-driven changes in hydrology [12-14].

\section{Methods}

\subsection{Study Area}

This study was conducted in two headwater catchments of the Clear Fork River of the Big Coal River located in southern West Virginia, USA (Figure 2). The Big Coal River is in the Appalachian Plateau physiographic region and is characterized as mountainous, deeply-incised terrain. Ridges are narrow and winding with a dendritic drainage networks dominated by ephemeral and perennial first-order streams that drain convergent hillslopes. Hillslopes are steep, and low slope areas are limited to ridge tops and valley bottoms. The Big Coal River watershed is underlain by sedimentary rocks primarily of the Pennsylvanian Age and, specifically, the Kanawha Formation of the Pottsville Group [38]. The Kanawha formation consists of massive beds of sandstone separated by thinner beds of shale, siltstone and coal [39]. Soils in this region are thin and shallow $(<1 \mathrm{~m})$ and underlain by the impermeable sedimentary rocks. Limited soil storage and steep slopes lead to rapid hydrograph response even in forested catchments [40]. Groundwater movement occurs primarily along horizontal and vertical stress relief fractures and responds quickly to surface moisture conditions [39,41,42].

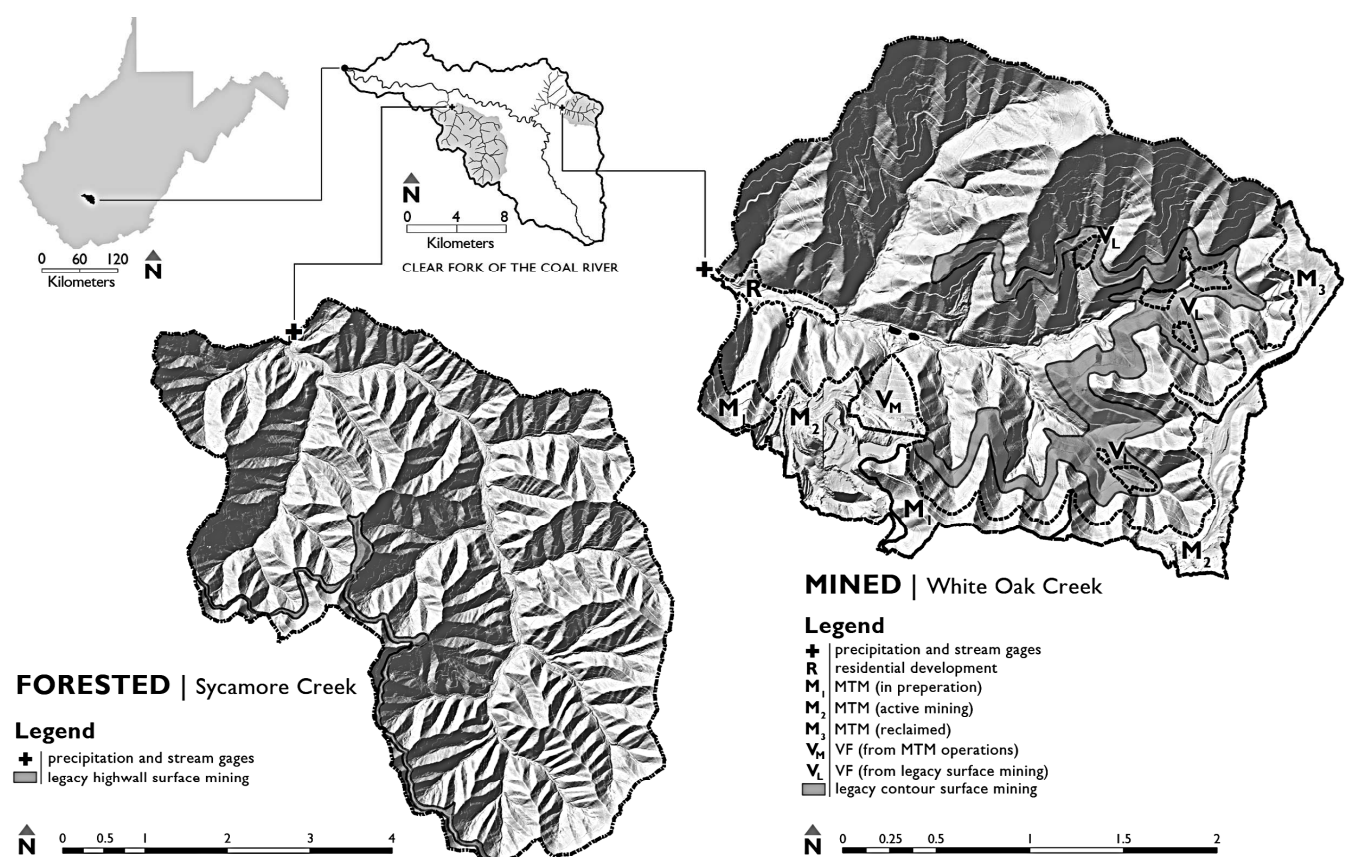

Figure 2. Location of the mountaintop mined White Oak Creek catchment and the forested Sycamore Creek catchment in the southern West Virginia Coalfields region. Hillshade and catchment boundaries were derived from a 1-m LiDAR DEM flown and processed by West Virginia University Natural Resource Analysis Center in April of 2010. Land use boundaries were digitized from 1-m aerial imagery from the 2011 National Agriculture Imagery Program (NAIP). 
This region experiences a humid continental climate with warm summers and cold winters. Average temperature during the warmest month (July) is $24^{\circ} \mathrm{C}$ and average temperature during the coldest month (January) is $0.5^{\circ} \mathrm{C}$. Average annual precipitation from 1973-2010 measured nearby at Madison, WV, is $1224 \mathrm{~mm}$ [34]. Precipitation is heavily influenced by prevailing wind direction and surface topography and is generally derived from frontal or tropical storm systems. Intense rainfalls frequently exceed $100 \mathrm{~mm}$ in a 24-h period [39]. Catastrophic flooding in small catchments $\left(<1000 \mathrm{~km}^{2}\right)$ in this region is often driven by orographic and convective thunderstorms [43].

White Oak Creek (herein referred to as mined) is a $6.5-\mathrm{km}^{2}$ catchment that drains primarily east to west where it confluences with the Clear Fork River near Artie, WV (Figure 2). Elevations range from 475-991 m; hillslope slopes average $55.6 \%$; the total stream length is $21 \mathrm{~km}$; and the drainage density is $3.3 \mathrm{~km} \mathrm{~km}^{-2}$ (Table 1). While second and third growth deciduous forest cover dominate the catchment, $17 \%\left(1.2 \mathrm{~km}^{2}\right)$ is impacted by recent MTM mining and by a large, partially reclaimed valley fill that occupies $\sim 2 \%\left(0.11 \mathrm{~km}^{2}\right)$ of the catchment area. The MTM area in this catchment can be classified into three distinct stages: preparation $\sim 4 \%)$, active mining $(\sim 10 \%)$ and reclaimed $(\sim 3 \%)$. Areas in preparation are characterized by the excavation of terraces around the section of ridges to be excavated; the initial removal of vegetation; and the development of temporary road networks. Actively-mined areas are completely devoid of vegetation and undergoing active excavation, and reclaimed areas have been regraded and revegetated with herbaceous grasses and minimal woody vegetation. In addition to MTM, traditional contour mining on the mid-slopes of the catchment occurred during the mid-1990s, impacting $~ 12 \%$ of the catchment area, all of which has been revegetated using herbaceous cover and reclaimed in accordance with the Surface Mining Control and Reclamation Act (SMCRA) [44]. As part of this operation, seven small valley fills were created on the incipient drainage network of White Oak Creek, although these structures are significantly smaller than valley fills associated with contemporary MTM practices. Typical of surface mining operations, two small retention ponds were constructed on the main stem White Oak Creek to control sedimentation originating from the surface mines. Outside of MTM areas, no timber extraction occurred in the catchment during or leading up to the study period, although it has been periodically harvested over the last several decades. Residential development in the catchment is limited to the valley floor with a small amount $\left(0.07 \mathrm{~km}^{2} ; \sim 1 \%\right)$ of light residential development located upstream of our stream gauge.

Sycamore Creek (forested) is a $25.5-\mathrm{km}^{2}$ forested catchment that drains primarily south to north until it confluences with the Clear Fork near the town of Colcord, WV (Figure 2). Elevations range from $333-1013 \mathrm{~m}$; hillslope slopes average $60.4 \%$; the total stream length is $70 \mathrm{~km}$; and drainage density is $2.75 \mathrm{~km} \mathrm{~km}^{-2}$ (Table 1). Second and third growth deciduous forest dominate the catchment ( $98 \%$ ). Similar to many headwater catchments in the Big Coal River basin, traditional contour mining extracted coal from this catchment during the 1970s, but analysis of aerial photography shows that this area has been reclaimed back to forest. MTM is absent from this catchment. Several small gas wells are located in the central valley, and a gravel access road parallels Sycamore Creek. In addition, two right-of-ways covered in grasses and herbaceous cover cross the catchment: a $50 \mathrm{~m}$-wide natural gas pipeline in the southern half of the catchment and a $30 \mathrm{~m}$-wide electric transmission line that runs north-south, paralleling Sycamore Creek for much of its length. Sycamore Creek has been timbered throughout history, but no active forest harvesting occurred leading up to or during the study period. An extensive network of logging roads from previous timbering and on-going gas operations follows the valley upstream. Light residential development in the broad floodplain is located downstream of our stream gauging station. 
Table 1. Catchment characteristics of the mined White Oak Creek catchment and the forested Sycamore Creek catchment.

\begin{tabular}{|c|c|c|c|c|c|c|c|c|c|c|c|c|c|c|c|}
\hline \multirow{3}{*}{ Catchment } & \multirow{2}{*}{\multicolumn{7}{|c|}{ A. }} & \multicolumn{4}{|c|}{ Surface Mining } & \multicolumn{4}{|c|}{ Underground Mining } \\
\hline & & & & & & & & B. & c. & D. & E. & F. & G. & H. & I. \\
\hline & $\begin{array}{l}\text { Station } \\
\text { Location }\end{array}$ & $\begin{array}{c}\text { Station } \\
\text { Elevation }\end{array}$ & $\begin{array}{l}\text { Catchment } \\
\text { Area }\end{array}$ & $\begin{array}{l}\text { Elevation } \\
\text { Change }\end{array}$ & Mean Slope & $\begin{array}{l}\text { Stream } \\
\text { Length }\end{array}$ & $\begin{array}{l}\text { Drainage } \\
\text { Density }\end{array}$ & Legacy $^{1}$ & MTM $^{2}$ & $\begin{array}{l}\text { Vally Fill Area / } \\
\text { \% Catchment } \\
\text { Area }^{3}\end{array}$ & $\begin{array}{c}\text { Total Surface } \\
\text { Mining } \\
\text { Disturbance }{ }^{4}\end{array}$ & $\begin{array}{l}\text { Catchment Area } \\
\text { Undermined }^{5}\end{array}$ & $\begin{array}{l}\text { Underground Mines } \\
\text { Contributing Area }^{6}\end{array}$ & $\begin{array}{c}\text { Catchment Area + } \\
\text { Underground Mines } \\
\text { Contributing Area }{ }^{7}\end{array}$ & 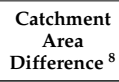 \\
\hline & (Lat/Long) & (m) & $\left(\mathrm{km}^{2}\right)$ & (m) & {$\left[{ }^{\circ}(\mathrm{Std}\right.$ Dev $\left.)\right]$} & $(\mathrm{km})$ & $\left(\mathrm{km} \mathrm{km}^{-2}\right)$ & {$\left[\%\left(\mathrm{~km}^{2}\right)\right]$} & {$\left[\%\left(\mathrm{~km}^{2}\right)\right]$} & {$\left[\%\left(\mathrm{~km}^{2}\right)\right]$} & {$\left[\%\left(\mathrm{~km}^{2}\right)\right]$} & {$\left[\%\left(\mathrm{~km}^{2}\right)\right]$} & $\left(\mathrm{km}^{2}\right)$ & $\left(\mathrm{km}^{2}\right)$ & $(\%)$ \\
\hline $\begin{array}{l}\text { White Oak Creek } \\
\text { (Mined) }\end{array}$ & $\begin{array}{l}37^{\circ} 56.47^{\prime} \\
-81^{\circ} 19.93^{\prime} \\
\end{array}$ & 475 & 6.5 & 516 & $55.6( \pm 19.2)$ & 21 & 3.3 & $10.4(0.8)$ & $17.3(1.1)$ & $2.9(0.2)$ & $31(2.1)$ & $84(5.4)$ & 15.5 & 22 & 238 \\
\hline $\begin{array}{c}\text { Sycamore Creek } \\
\text { (Forested) }\end{array}$ & $\begin{array}{l}37^{\circ} 56.47^{\prime} \\
-81^{\circ} 26.01^{\prime}\end{array}$ & 333 & 25.5 & 680 & $60.4( \pm 13.7)$ & 70 & 2.8 & $2.1(0.5)$ & 0 & 0 & $0.5(2.0)$ & $20(5.2)$ & 20 & 45.5 & 80 \\
\hline
\end{tabular}

${ }^{1}$ Legacy surface mining consists of traditional surface mining practices that include highwall mining and contour mining. In White Oak Creek contour surface mining took place during the 1990s. This area was reclaimed and is currently covered by herbacous grasses and some woody vegetations. In Sycamore Creek, highwall mining took place on the western ridge during the $1970 \mathrm{~s}$. The highwall and mining bench were not reclaimed, but natural succession of deciduous forest has occurred. ${ }^{2}$ MTM in White Oak Creek consists of areas "in preparation" $\left(0.3 \mathrm{~km}^{2}\right)$, "active surface mining" $\left(0.7 \mathrm{~km}{ }^{2}\right)$, and "reclaimed"
$\left(0.2 \mathrm{~km}^{2}\right)$. ${ }^{3}$ Valley fills in White Oak Creek consists of one large contemporary valley fill $\left(0.1 \mathrm{~km}^{2}\right)$ and several fills $\left(0.1 \mathrm{~km}^{2}\right) .{ }^{4}$ Calculated as B $+\mathrm{C}+\mathrm{D} .{ }^{5} \mathrm{Underground}$ mining within topographically delineated catchment area. ${ }^{6}$ Area of Creek consists of one large contemporary valley fill $\left(0.1 \mathrm{~km}^{2}\right)$ and several fills $\left(0.1 \mathrm{~km}^{2}\right) .{ }^{4}$ Calculated as $\mathrm{B}+\mathrm{C}+\mathrm{D}$. ${ }^{5}$ Underground mining within topographically delineated catchment area and contributing area (surface + underground mining). Calculated as (H-A)/A. 
Underground coal mining throughout the Appalachian Coalfields region began in late 1800s and in the 1930s in the Big Coal River basin. To quantify the extent of underground mining throughout the region and to assess the potential for confounding impacts of underground mine disturbance and inter-basin transfer, coal geology and mining activity maps were acquired from the West Virginia University Natural Analysis Resources Center and analyzed in GIS to determine the dip direction of coal seams and to estimate the regional and local extent of underground mining. The subsurface contributing recharge area for each catchment was estimated by calculating the area of individual and overlapping up-dip, underground coal mines. Coal seams in this region often overlap and merge $[45,46]$, and the actual extent, integrity and connectivity of underground mines is highly uncertain without detailed field reconnaissance. As a result, subsurface recharge areas are gross estimates. Digital coal geology and mining activity data are made publicly available from the West Virginia Department of Environmental Protection TAGIS group (http://tagis.dep.wv.gov/home/).

\subsection{Instrumentation, Data Collection and Analyses}

Precipitation and streamflow were measured upstream of catchment outlets from 1 September 2011-30 September 2012. Precipitation was measured using TE525-L tipping bucket rain gauges installed in clearings located adjacent to each stream gauging station (Figure 2) and recorded using Campbell Scientific (Logan, UT, USA) CR 800 data loggers at 10-minute intervals. Stream stage was measured using Campbell Scientific CS450 pressure transducers installed along stream reaches and also recorded at 10-min intervals using CR 800 data loggers. The recorded stream stage was converted to streamflow using stage-streamflow rating curves developed for each location. Streamflow was measured using the velocity area methodology [47] using a SonTek Handheld Acoustic Doppler Velocimeter and verified using the salt tracer dilution method [48]. The rating curve for the mined catchment was developed using eight measurements ranging from $0.02-1.21 \mathrm{~mm} \mathrm{~h}^{-1}\left(r^{2}=0.99\right)$ and using 10 measurements ranging from $0.001-0.84 \mathrm{~mm} \mathrm{~h}^{-1}\left(r^{2}=0.99\right)$ for the forested catchment. Seven months into the study period, the stream gauging station in the forested catchment was moved $5 \mathrm{~m}$ downstream to a bedrock controlled pool to minimize measurement error associated with sedimentation. The original pressure transducer elevation was surveyed and marked using a 1-m re-bar pin, and a stage at the new location was adjusted using a correction factor.

Rainfall duration, depth and intensity and total unit runoff, peak flow, time-to-peak and the runoff ratio $(\mathrm{Q} / \mathrm{P})$ were characterized for each event. In addition, events were separated into quickflow [49], and hydrologic response times were modeled using a runoff transfer function approach [50,51] (see below). Events were defined by one hour prior to the onset of rain and until the stream stage returned to pre-storm base flow levels or when stream recession was interrupted by a second storm event.

Events-based isotope samples were collected by interfacing Isco automated water samplers (Model 3700, Teledyne ISCO, Inc., Lincoln, NE, USA) with precipitation and stream stage data loggers. Precipitation samplers consisted of 200-mm funnels connected to tubing that bypassed the Isco pump and fed directly into the Isco distribution arm to distribute samples to 1000-mL polyethylene bottles. After the onset of precipitation, rainfall water samples were collected incrementally every hour and/or after exceeding a 7.0-mm threshold. This enabled capturing isotopic variation during events $[52,53]$ and allowed for event precipitation to be weighted for mixing models [54]. Stream water was collected once daily during base flow conditions and between 3- and 6-h intervals during event rising, peak and falling limbs. All Isco bottles were lined with 2-oz Nasco sample bags pre-treated with mineral oil to prevent fractionation from evaporation. Samples were separated from mineral oil by puncturing the bottom of the sample bag and draining water into a $25-\mathrm{mL}$ cone capped scintillation vial for storage until processing. Isotope samples were collected for all storms during the study period, except from December 2011-March 2012, when precipitation fell as snow or frozen rain.

Water samples were analyzed for deuterium $(D)$ and oxygen-18 $\left({ }^{18} \mathrm{O}\right)$ using a laser-based liquid water isotope analyzer (DLT-100 Version 2, Los Gator Research, Inc., San Jose, CA, USA) located at the West Virginia University Mountain Hydrology Laboratory. In-house standards were developed 
by calibrating Hawaiian spring water enriched with heavy isotopes and Colorado spring water depleted of heavy isotopes to the Vienna-Standard Mean Ocean Water (VSMOW) issued by the International Atomic Energy Association (IAEA). Isotope values are reported in per mil (\%o) [55] relative to a standard as $\delta \mathrm{D}$ or $\delta^{18} \mathrm{O}$. The precision reported was $0.58(\%)$ and $0.11(\%)$ for $\delta \mathrm{D}$ and $\delta^{18} \mathrm{O}$, respectively.

\subsection{Hydrograph Separation and Response Time Modeling}

Streamflow was separated into event and pre-event components using two isotope hydrograph separation methods: a traditional two-component mixing model $[56,57]$ and the transfer function hydrograph separation (TRANSEP) model [58]. Hydrograph separation using these approaches is based on the assumption that pre-event water composition is constant in space and time [57] and that streamflow can be separated into event and prevent components:

$$
\begin{gathered}
Q=Q_{p}+Q_{e} \\
Q C=Q_{p} C_{p}+Q_{e} C_{e}
\end{gathered}
$$

where $Q$ is streamflow; $Q_{p}$ and $Q_{e}$ are contributions from pre-event and event water; and $C, C_{p}, C_{e}$ are $\mathrm{D}$ or ${ }^{18} \mathrm{O}$ concentrations in streamflow, pre-event and event water [58].

It is well accepted that the isotopic composition of rain water changes through time [52,53], and therefore, the rainfall composition used in the traditional two-component mixing model was incrementally weighted by rainfall intensity [54]:

$$
\delta D \text { or } \delta^{18} O=\sum_{i=1}^{n} I i \delta i / \sum_{i=1}^{n} I i
$$

where $I i$ is the average rainfall intensity in $\mathrm{mm} \mathrm{h}^{-1} ; \delta \mathrm{i}$ is the measured rainfall isotopic composition during the increment.

While this weighting approach accounts for temporal variability and mass tracer allocation [58], it assumes an instantaneous transfer of event water to the stream and does not incorporate travel time, which is an important descriptor of catchment hydrology. The TRANSEP model, on the other hand, integrates isotope hydrograph separation and an instantaneous unit hydrograph approach to model rainfall-runoff dynamics and travel times. We only briefly describe TRANSEP below; more details can be found in [58] and [59].

The TRANSEP model uses a simple rainfall-runoff model consisting of a nonlinear module that converts precipitation into effective precipitation [50] and a linear model that represents the transformation of effective rainfall into streamflow [58]. TRANSEP requires the a priori selection of transfer functions for both the runoff and the transport transfer function [60]. Based on our previous work in these catchments [34] and successful application in other studies [58,59,61], we used the two parallel linear reservoirs (TPLR) [58] transfer function. The runoff transfer function was optimized to measured streamflow using ant colony optimization (AOC) $[58,62]$ and then used to constrain the optimization of the transport transfer function on the basis of observed isotope compositions and effective precipitation [60]. One hundred thousand Monte Carlo simulations were used to explore parameter sensitivity and to calculate median hydrologic response times from the cumulative distribution function for the top 1\% performing models based on the Nash-Sutcliffe efficiency (NSE) objective function [63]. 


\section{Results}

\subsection{Extent of Underground Mining}

Based on our analysis, underground coal mining underlies approximately 1.2 million hectares or $25 \%$ of the MTM region (Figure 1), and underground mining below the study catchments is extensive (Figure 3). While no underground mines are located directly under the main stems of either of the creeks, underground coal mining has occurred under headwater tributaries of both catchments.

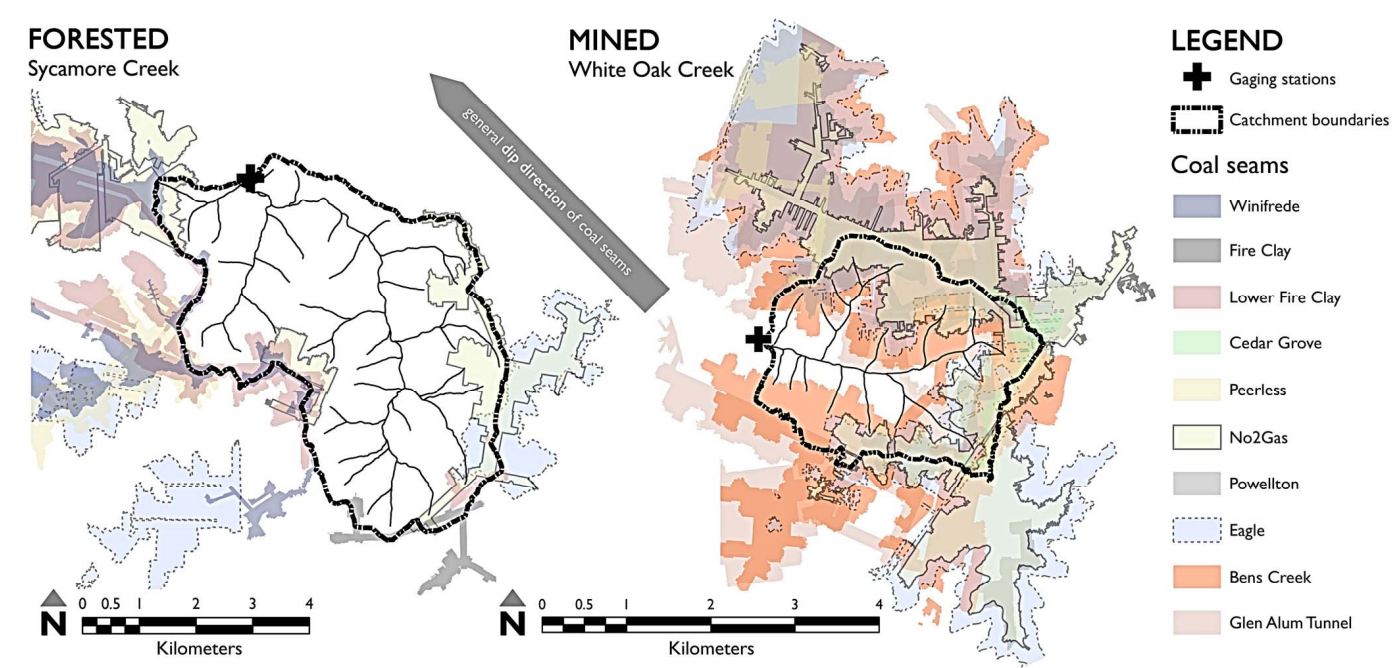

Figure 3. Underground mines below the mountaintop mined White Oak Creek and the forested Sycamore Creek catchments. Coal seams are listed in stratigraphic order, and the dip direction is northwest. Mean dip in the mined catchment is $0.92^{\circ}$ and $0.74^{\circ}$ in the forested catchment. Approximately $85 \%$ of the mined catchment area and $20 \%$ of the forested catchment area are directly underlain by underground mines. When including up-dip underground mine areas, the contributing drainage area increases over the topographically-delineated area by $\sim 240 \%$ in the mined catchment and by $>80 \%$ in the forested catchment.

Seven coal seams of the Kanawha formation were mined under the eastern, southern and western hillslopes of the MTM mined catchment (Figure 3) with $\sim 85 \%$ of the catchment having been directly undermined (Table 1). Underground mined areas up-dip of the stream gauging station, or the underground recharge area, were approximately $15.5 \mathrm{~km}^{2}$, increasing the effective drainage area to $22 \mathrm{~km}^{2}$. Underground mining has occurred as recently as 2008 and extends deeper into the Kanawha formation than under the forested catchment, mining the Ben's Creek and Glen Alum Tunnel coal seams. Six coal seams were mined under the eastern, southern and western hillslopes of the forested catchment (Figure 3) with $\sim 20 \%$ of the catchment having been directly undermined (Table 1). Underground mine contributing area in this catchment was approximately $20 \mathrm{~km}^{2}$, increasing the effective drainage area to $\sim 46 \mathrm{~km}^{2}$. The deepest seam mined below this catchment was the Eagle seam. The dip direction of the coal seams in the area runs southeast to northwest at a slope of $\sim 0.91^{\circ}$ in the mined catchment and $\sim 0.74^{\circ}$.

\subsection{Rainfall-Runoff Relationships}

Rainfall over the thirteen-month study period totaled $1470 \mathrm{~mm}$ in the mined catchment and $1511 \mathrm{~mm}$ in the forested catchments. Runoff averaged $914 \mathrm{~mm}$ (62\% of P) and $322 \mathrm{~mm}(21 \%$ of P), respectively. Rainfall was mostly evenly distributed throughout the year with slightly more skew 
towards spring and early summer. Flow duration curves for the two catchments were markedly different for all but the largest flows (Figure 4).

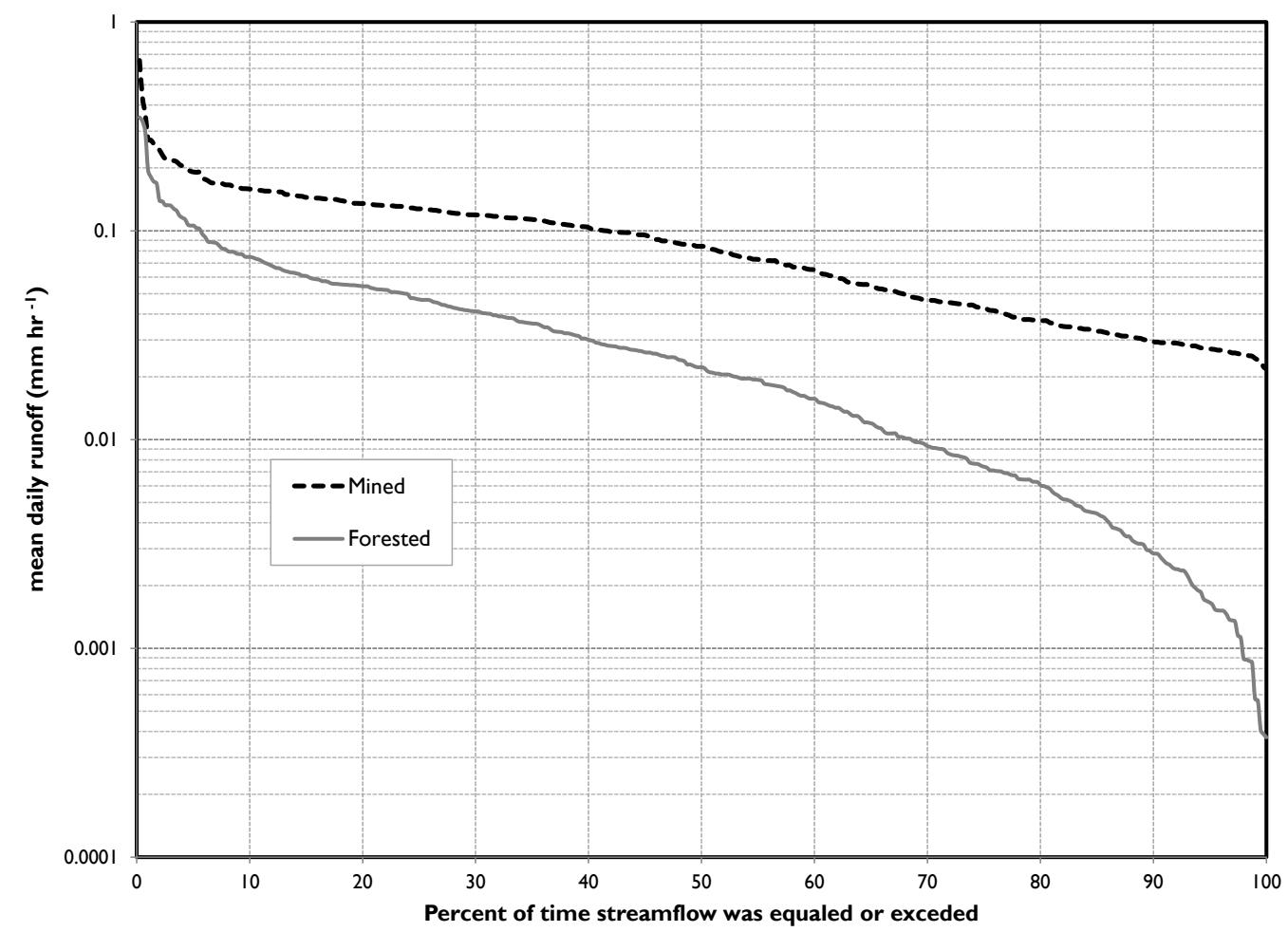

Figure 4. Flow duration curves for the mined and forested catchments from 1 September 2011-30 September 2012 showing the different flow regimes; runoff in the mined catchment is consistently greater than the forested catchment during all times of the study period, particularly during base flow conditions when flow is sustained by valley fills.

The twenty-three events that were used to characterize rainfall-runoff and hydrologic responses of our two study catchments are shown in Figure 5 and summarized in Table 2. Several events occurring in late-December-January and in February were excluded from the analysis because precipitation either fell as snow or as freezing rain and was under-measured by tipping bucket rain gauges. Event rainfall duration, total rainfall, rainfall intensity and maximum rainfall intensity were similar for the two catchments based on the Wilcoxon signed rank test (Figure 6). Events that occurred during the dormant season were generally lower in intensity, longer in duration and had more total rainfall than growing season events (Table 2). 

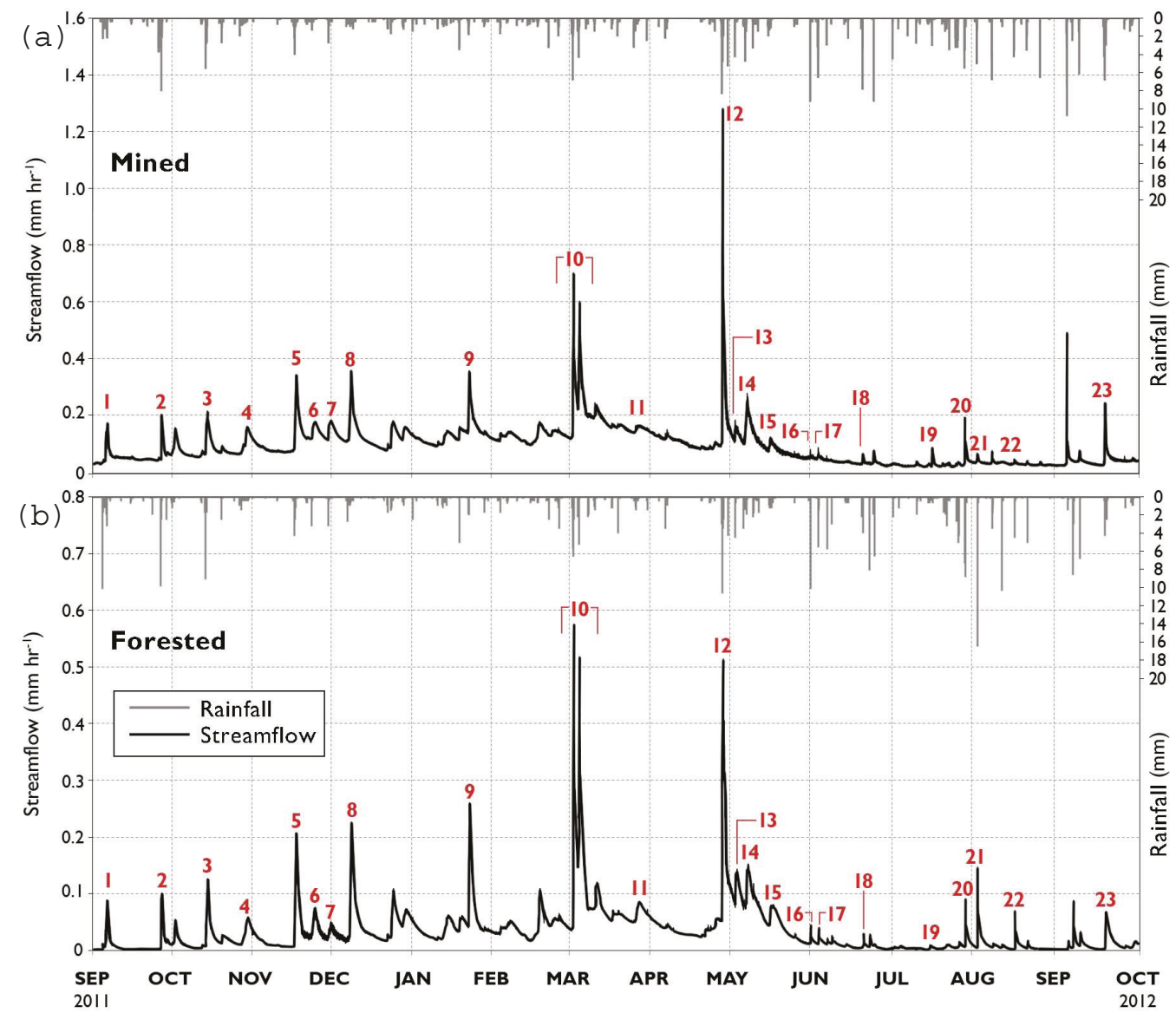

Figure 5. Storm event hydrographs and hyetographs for the (a) mined and (b) forested catchments for the study period from September 2011-October 2012. The storm events included in the analyses are noted sequentially. The large storm in the mined catchment in late September 2012 was excluded from analysis because the vent tube to compensate for atmospheric pressure was incorrectly assembled after exchanging desiccant. 
Table 2. Rainfall and runoff storm characteristics and hydrologic response times for 23 events measured in the mined and forested catchment over the 13 -month study period. Dormant season events are shaded.

\begin{tabular}{|c|c|c|c|c|c|c|c|c|c|c|c|c|c|c|c|c|c|c|c|c|}
\hline \multirow{3}{*}{ Event } & \multirow{3}{*}{ Event Start ${ }^{a}$} & & \multicolumn{9}{|c|}{ Mined Catchment } & \multicolumn{9}{|c|}{ Forested Catchment } \\
\hline & & & \multicolumn{3}{|c|}{ Rainfall } & \multicolumn{6}{|c|}{ Runoff } & \multicolumn{3}{|c|}{ Rainfall } & \multicolumn{6}{|c|}{ Runoff } \\
\hline & & & Duration & Depth & Intensity & $\begin{array}{c}\text { Total } \\
\text { Streamflow }\end{array}$ & $\mathrm{Q} / \mathrm{P}$ & Peak Flow & Time-to-Peak $^{\mathrm{c}}$ & Lag $^{d}$ & $Q f / Q^{e}$ & Duration & Depth & Intensity & $\begin{array}{c}\text { Total } \\
\text { Streamflow }\end{array}$ & $\mathrm{Q} / \mathrm{P}$ & Peak Flow & Time-to-Peak $^{\mathrm{c}}$ & $\operatorname{Lag}^{\mathrm{d}}$ & $Q f / Q^{e f}$ \\
\hline \multicolumn{2}{|r|}{ Date } & Time $^{\mathrm{b}}$ & (hr) & (mm) & $\left(\mathrm{mm} \mathrm{hr}^{-1}\right)$ & $(\mathrm{mm})$ & - & $\left(\mathrm{mm} \mathrm{hr}^{-1}\right)$ & (hr) & (hr) & - & (hr) & $(\mathrm{mm})$ & $\left(\mathrm{mm} \mathrm{hr}^{-1}\right)$ & $(\mathrm{mm})$ & - & $\left(\mathrm{mm} \mathrm{hr}^{-1}\right)$ & (hr) & (hr) & - \\
\hline \multirow{3}{*}{\multicolumn{2}{|c|}{$\begin{array}{c}04 \text { September } 2011 \\
26 \text { September } 2011 \\
11 \text { October } 2011\end{array}$}} & 1440 & 41.7 & 65.0 & 1.6 & 16.4 & 0.25 & 0.18 & 41.7 & 1.5 & 0.08 & 78.5 & 90.9 & 1.2 & 2.7 & 0.03 & 0.09 & 42.0 & 41.5 & - \\
\hline & & 1510 & 12.7 & 48.0 & 3.8 & 5.2 & 0.11 & 0.21 & 4.7 & 1.2 & 0.27 & 10.0 & 62.0 & 6.2 & 2.1 & 0.03 & 0.10 & 10.3 & 6.7 & 0.42 \\
\hline & & $\begin{array}{l}1930 \\
1130\end{array}$ & $\begin{array}{l}55.8 \\
68.3\end{array}$ & $\begin{array}{l}51.8 \\
34.8\end{array}$ & 0.9 & $\begin{array}{l}17.3 \\
3.4\end{array}$ & $\begin{array}{l}0.33 \\
0.99\end{array}$ & 0.22 & $\begin{array}{l}57.5 \\
65.2\end{array}$ & $\begin{array}{l}15.5 \\
65.2\end{array}$ & $\begin{array}{r}0.13 \\
0.02\end{array}$ & $\begin{array}{l}55.7 \\
65.8\end{array}$ & $\begin{array}{l}49.5 \\
307\end{array}$ & 0.9 & $\begin{array}{r}5.5 \\
6.9\end{array}$ & 0.11 & 0.13 & 61.7 & 20.0 & 0.17 \\
\hline \multicolumn{2}{|r|}{$\begin{array}{l}26 \text { October } 2011 \\
15 \text { November } 2011\end{array}$} & $\begin{array}{l}1130 \\
0500\end{array}$ & $\begin{array}{l}68.3 \\
52.7\end{array}$ & $\begin{array}{l}34.8 \\
49.0\end{array}$ & $\begin{array}{l}0.5 \\
0.9\end{array}$ & $\begin{array}{l}34.4 \\
20.8\end{array}$ & $\begin{array}{l}0.99 \\
0.42\end{array}$ & $\begin{array}{l}0.17 \\
0.35\end{array}$ & $\begin{array}{l}65.2 \\
37.7\end{array}$ & $\begin{array}{l}65.2 \\
10.8\end{array}$ & $\begin{array}{l}0.02 \\
0.21\end{array}$ & $\begin{array}{l}6.8 \\
52.3\end{array}$ & $\begin{array}{l}30.7 \\
49.5\end{array}$ & $\begin{array}{l}0.5 \\
0.9\end{array}$ & $\begin{array}{l}6.9 \\
7.7\end{array}$ & 0.23 & 0.06 & $\begin{array}{l}73.5 \\
337\end{array}$ & $\begin{array}{l}55.3 \\
113\end{array}$ & - \\
\hline \multicolumn{2}{|r|}{20 November 2011} & 1010 & 71.7 & $\begin{array}{l}43.0 \\
23.4\end{array}$ & 0.3 & 25.3 & $\begin{array}{l}0.42 \\
1.08\end{array}$ & $\begin{array}{l}0.18 \\
0.18\end{array}$ & 84.0 & $\begin{array}{l}10.8 \\
25.7\end{array}$ & $\begin{array}{l}0.21 \\
0.02\end{array}$ & $\begin{array}{l}51.3 \\
71.0\end{array}$ & $\begin{array}{l}49.5 \\
23.1\end{array}$ & $\begin{array}{l}0.9 \\
0.3\end{array}$ & 6.0 & $\begin{array}{l}0.16 \\
0.26\end{array}$ & 0.08 & 86.5 & $\begin{array}{l}11.3 \\
28.3\end{array}$ & 0.35 \\
\hline \multirow{2}{*}{\multicolumn{2}{|c|}{$\begin{array}{l}29 \text { November } 2011 \\
05 \text { December } 2011\end{array}$}} & 0020 & 34.8 & 22.4 & 0.6 & 20.1 & 0.90 & 0.19 & 20.8 & 18.8 & 0.03 & 34.5 & 16.8 & 0.5 & 3.7 & 0.22 & 0.05 & $\begin{array}{l}80.3 \\
24.3\end{array}$ & $\begin{array}{l}28.3 \\
23.0\end{array}$ & - \\
\hline & & 1950 & 63.7 & 46.5 & 0.7 & 30.7 & 0.66 & 0.36 & 43.3 & 5.2 & 0.09 & 63.2 & 50.6 & 0.8 & 15.4 & 0.31 & 0.22 & 47.5 & 37.7 & $0 . \overline{19}$ \\
\hline \multicolumn{2}{|c|}{20 January 2012} & 1720 & 63.5 & 32.3 & 0.5 & 26.0 & 0.80 & 0.36 & 16.7 & 5.3 & 0.12 & 63.3 & 33.3 & 0.5 & 10.8 & 0.33 & 0.26 & 17.7 & 7.0 & 0.31 \\
\hline \multirow{2}{*}{\multicolumn{2}{|c|}{ C 29 Feburary 2012}} & 0450 & 151.0 & 88.9 & 0.6 & 57.5 & 0.65 & 0.70 & 17.8 & 5.0 & 0.23 & 70.5 & 73.9 & 1.0 & 30.4 & 0.41 & 0.58 & 17.5 & 7.3 & 0.43 \\
\hline & & 1320 & 127.7 & 27.2 & 0.2 & 25.5 & 0.94 & 0.17 & 49. & & & & & & & & & & & - \\
\hline \multicolumn{2}{|r|}{$\begin{array}{l}23 \text { March } 2012 \\
25 \text { April } 2012\end{array}$} & & & 75.7 & 1.0 & 34.3 & 0.45 & 1.30 & 19.7 & 9.0 & 0.46 & 78.0 & 86.9 & 1.1 & 20.9 & 0.24 & 0.51 & 19.8 & 9.7 & 0.37 \\
\hline \multicolumn{2}{|r|}{$\quad 30$ April 2012} & 2340 & 26.3 & 19.6 & 0.7 & $\begin{array}{l}5.8 \\
9.8\end{array}$ & 0.50 & 0.19 & 3.3 & 3.2 & 0.04 & 22.0 & 23.4 & 1.1 & 7.5 & 0.32 & 0.14 & $\begin{array}{l}16.7 \\
16.7\end{array}$ & 16.3 & 0.08 \\
\hline 14 & 04 May 2012 & 2330 & 127.3 & 47.8 & 0.4 & 21.4 & 0.45 & 0.28 & 35.5 & 17.0 & 0.12 & 117.2 & 37.3 & 0.3 & 13.5 & 0.36 & 0.15 & 23.3 & 15.3 & 0.04 \\
\hline & 1700 & 38.3 & 26.7 & 0.7 & 9.6 & 0.36 & 0.13 & 20.5 & 16.3 & 0.02 & 60.7 & 26.2 & 0.4 & 7.9 & 0.30 & 0.08 & 41.3 & 32.0 & 0.02 \\
\hline 16 & \multirow{2}{*}{$\begin{array}{l}29 \text { May } 2012 \\
\text { 01 June } 2012\end{array}$} & 1300 & 1.5 & 16.5 & 11.0 & 1.1 & 0.07 & 0.08 & 1.5 & 1.5 & 0.05 & 1.3 & 19.6 & 14.7 & 0.8 & 0.04 & 0.05 & 1.2 & 1.0 & 0.10 \\
\hline 17 & & 0300 & 10.8 & 20.3 & 1.9 & 2.7 & 0.13 & 0.09 & 10.5 & 1.5 & 0. & 11.8 & 17.3 & 1.5 & 1.5 & 0.08 & 0.04 & 13.0 & 3.7 & 0.05 \\
\hline 18 & $\begin{array}{l}\text { 01 June } 2012 \\
\text { 17 June } 2012\end{array}$ & 2000 & 14.3 & 18.8 & 1.3 & 2.2 & 0.12 & 0.07 & 14.5 & 1.3 & 0. & 14.2 & 15.2 & 1.1 & 0.7 & 0.04 & 0.03 & 15.2 & 2.7 & 0.07 \\
\hline & 12 July 2012 & 2110 & 67.2 & 24.4 & 0.4 & 4.2 & 0.17 & & 45.2 & 1.2 & 0.0 & 92.7 & 21.1 & 0.2 & 0.6 & 0.03 & 0.01 & 17.8 & 14.3 & - \\
\hline 20 & & 2050 & 95.7 & 39.9 & 0.4 & 5.8 & 0.14 & 0.20 & 2.3 & 1.3 & 0.16 & 15.0 & 41.4 & 2.8 & 1.9 & 0.05 & 0.09 & 4.2 & 2.5 & 0.21 \\
\hline 21 & $\begin{array}{l}31 \text { July } 2012 \\
14 \text { Angus } 2012\end{array}$ & 1500 & 6.7 & 21.1 & 3.2 & 1.8 & 0.08 & 0.07 & 5.5 & 2.7 & 0.04 & 114.2 & 68.8 & 0.6 & 3.1 & 0.04 & 0.15 & 1.8 & 1.7 & 0.29 \\
\hline \multirow{2}{*}{\multicolumn{2}{|c|}{$\begin{array}{lc}2 & 14 \text { August } 2012 \\
3 & 17 \text { September } 2012\end{array}$}} & $\begin{array}{l}1500 \\
1410\end{array}$ & ${ }_{417}^{18.8}$ & $\begin{array}{l}12.7 \\
597\end{array}$ & 0.7 & 1.4 & $\begin{array}{l}0.11 \\
0 ? 0\end{array}$ & $\begin{array}{l}0.05 \\
0.25\end{array}$ & $\begin{array}{r}2.8 \\
137\end{array}$ & 0.8 & 0.01 & 70.3 & $\begin{array}{l}14.5 \\
41.9\end{array}$ & 0.2 & 1.4 & 0.10 & 0.07 & $\begin{array}{r}4.2 \\
157\end{array}$ & $\begin{array}{l}2.0 \\
8.0\end{array}$ & 0.15 \\
\hline $23 \quad 1$ & & 1410 & 41.7 & 59.7 & 1.4 & 11.7 & 0.20 & 0.25 & 13.7 & 0.8 & 0.12 & 31.0 & 41.9 & 1.4 & 3.5 & 0.08 & 0.07 & 15.7 & 8.0 & 0.13 \\
\hline & $\begin{array}{l}\text { Average } \\
\text { Std. Dev. }\end{array}$ & & $\begin{array}{l}55.3 \\
40.7\end{array}$ & $\begin{array}{l}37.9 \\
20.4\end{array}$ & $\begin{array}{l}1.5 \\
2.3\end{array}$ & $\begin{array}{l}16.7 \\
14.2\end{array}$ & $\begin{array}{l}0.43 \\
0.33\end{array}$ & $\begin{array}{l}0.26 \\
0.27\end{array}$ & $\begin{array}{l}26.7 \\
22.8\end{array}$ & $\begin{array}{l}11.3 \\
16.3\end{array}$ & $\begin{array}{l}0.10 \\
0.11\end{array}$ & $\begin{array}{l}54.1 \\
32.3\end{array}$ & $\begin{array}{l}39.6 \\
23.4\end{array}$ & $\begin{array}{l}1.7 \\
3.1\end{array}$ & $\begin{array}{l}7.3 \\
7.4\end{array}$ & $\begin{array}{l}0.20 \\
0.17\end{array}$ & $\begin{array}{l}0.14 \\
0.14\end{array}$ & $\begin{array}{l}28.1 \\
23.4\end{array}$ & $\begin{array}{l}16.6 \\
15.1\end{array}$ & $\begin{array}{l}0.20 \\
0.14\end{array}$ \\
\hline
\end{tabular}

Start times defined as start of precipitation in the forested catchment. $b$ Time listed in Eastern Standard Time (EST). ${ }^{c}$ Time to peak defined as time from start of precipitation to peak discharge. ${ }^{\mathrm{d}}$ Time lag defined as time from maximum instantaneous storm intensity to peak discharge. ${ }^{\mathrm{e}} \mathrm{QF} / \mathrm{Q}$ is the ratio of quickflow to total flow based on Hewlett and Hippert (1967). ${ }^{\mathrm{f}}$ Hydrograph separation unsuccessful for events 1,4,6,7,11,19 due to the separation slope being greater than the rising limb of the hydrograph. 


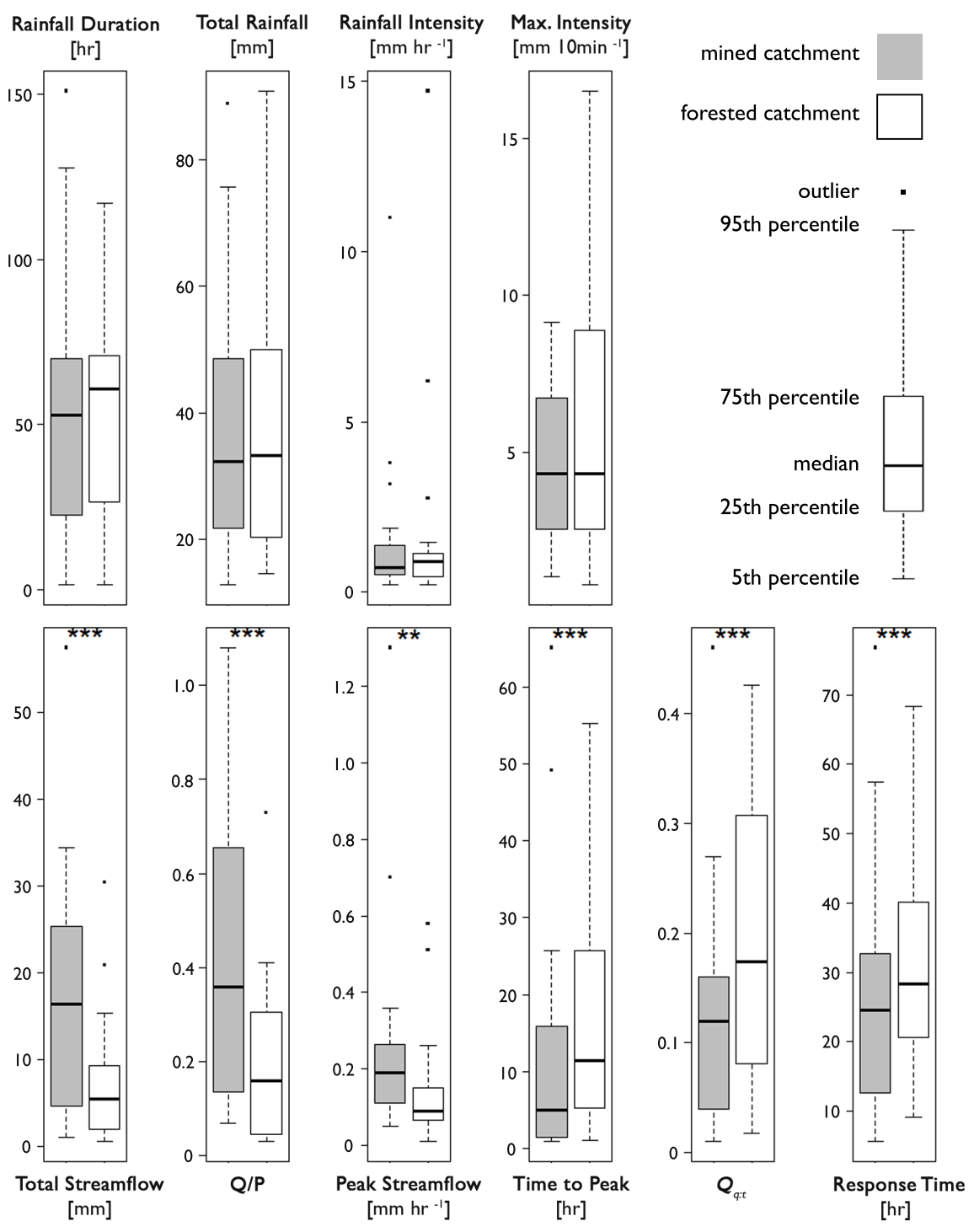

Figure 6. Event rainfall and runoff boxplots for the mined and forested catchments over 23 storm events that occurred during September 2011-October 2012. ${ }^{* * *}$ and ${ }^{* *}$ indicate statistically-significant differences at the $99 \%$ and $95 \%$ confidence level based on the Wilcoxon signed rank test. Statistically-significant differences in rainfall characteristics were not detected. Q/P represents the runoff ratio; Qqis the fraction of quickflow [49]. Median response times were calculated from the cumulative distribution function of the top 1000 performing transfer function models.

Runoff characteristics for the 23 events are shown by catchment in Figure 6 and summarized in Table 2. Total unit streamflow, peak flow and runoff ratio were generally larger in the mined catchment, while the time-to-peak and quickflow ratio were greater in the forested catchment irrespective of season. Time-to-peak was faster during the growing season in the mined catchment, but similar to the forested catchment during the dormant season.

Quickflow ratios for both catchments were generally greater during the dormant season (Table 2). In addition, we found that quickflow was strongly correlated with gross precipitation in both catchments (mined: $r^{2}=0.78, p$-value $<0.0001$; forested: $r^{2}=0.68, p$-value $=0.003$ ). When quickflow and precipitation were compared across growing and dormant seasons, a threshold pattern emerged (Figure 7). Below a threshold of around $30 \mathrm{~mm}$, the relationship between precipitation and quickflow was significant and strongly correlated in both catchments during the growing season (mined: $r^{2}=0.76$, 
$p$-value $<0.01$; forested: $r^{2}=0.99, p$-value $\left.<0.01\right)$. Above this value, precipitation and quickflow were moderately correlated in the mined catchment $\left(r^{2}=0.32, p\right.$-value $\left.=0.49\right)$ and strongly correlated in the forested catchment $\left(r^{2}=0.76, p\right.$-value $\left.=0.08\right)$. During the dormant season, the inverse was true in the mined catchment; precipitation and quickflow were significant and correlated during the dormant season $\left(r^{2}=0.92, p\right.$-value $\left.=0.02\right)$. Of the four dormant season events in the forested catchment, only one below-threshold event was successfully separated into quickflow [49] and, hence, inference below the threshold was limited.
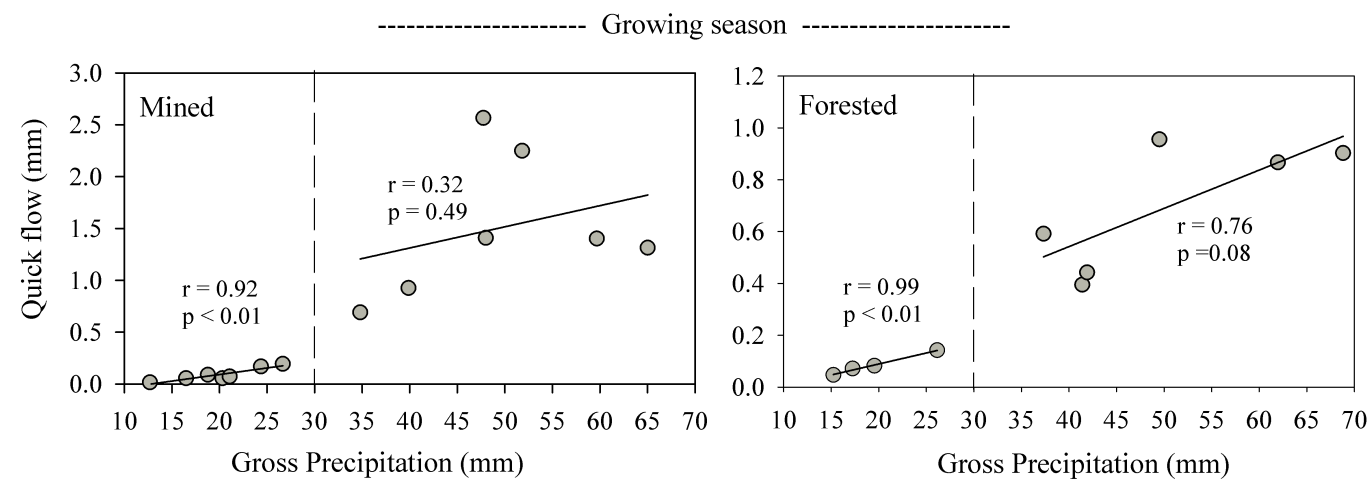

Dormant season
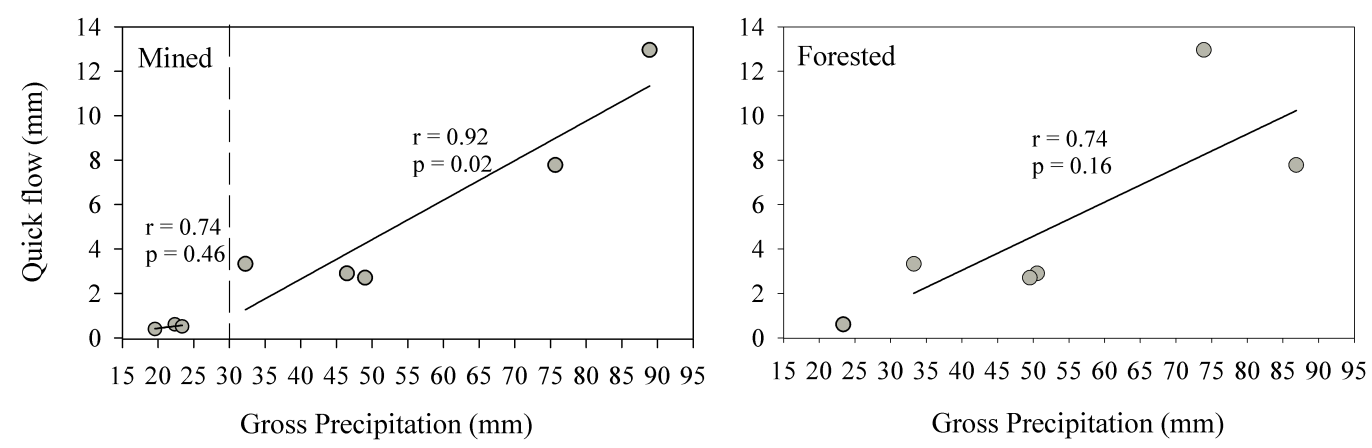

Figure 7. Gross precipitation and quickflow for all events based on the growing season and the dormant season for the mined and forested catchment. The threshold value is $\sim 30 \mathrm{~mm}$. Quickflow response is non-linear and generally more variable above threshold values. $r^{2}$ is the coefficient of determination based on regression analysis

\subsection{Runoff Modeling and Isotope Hydrograph Separation}

Storm event response times determined from the top $1 \%$ performing models (NSE > 0.97) are shown in Table 2, and box plots are shown in Figure 6. Model parameters were generally poorly identified (dotty plots not shown), a common problem with rainfall-runoff models [64]. Response times were generally faster $(26.3 \pm 17.1 \mathrm{~h})$ in the mined catchment than the forested catchment $(31.0 \pm 15.2 \mathrm{~h})$ and consistently faster and less variable during the dormant season than the growing season for both catchments. The shape of the response curves (Figure 8) reflects the TPLR model structure where effective precipitation is partitioned into fast and slow draining reservoirs. The steeply sloped recession in the first $20-30 \mathrm{~h}$ represents the initial period when the fast draining reservoir is active, whereas the longer, more gradual recession beyond $30 \mathrm{~h}$ is the depletion of the slow draining reservoir. In general, response curves for the mined catchment were more variable than the forested catchment and more variable for both catchments early and later on during storms. 


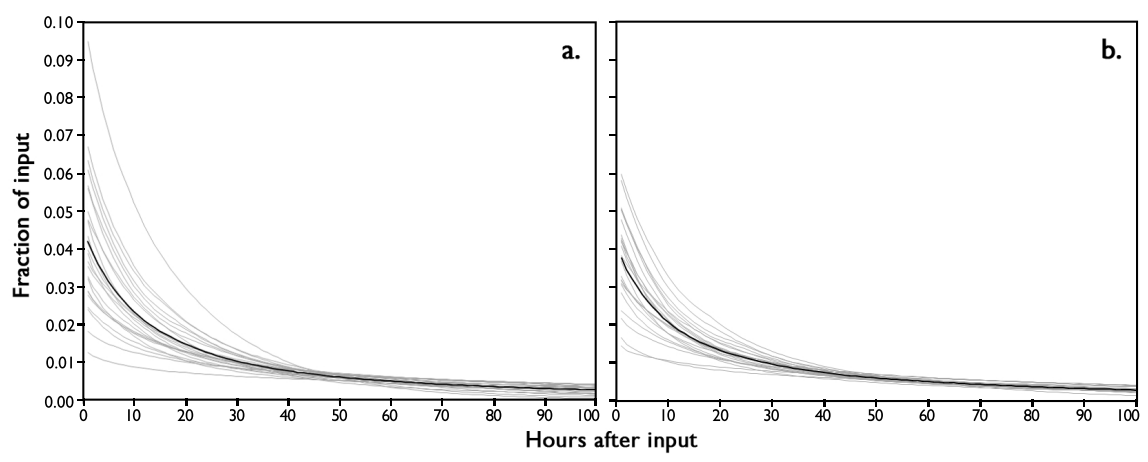

Figure 8. Hydrologic response curves for the 23 storm events in the (a) mined and (b) forested catchments. Response curves for individual events are shown in gray; black line shows the average of response curves for each catchment.

Of the 23 events analyzed in this study, only nine had complete isotope records, and only one of these events (Event 20) was separated into pre-event and event water contributions using both isotopes and mixing models. In both catchments, runoff was dominated by pre-event water $(72 \%-79 \%)$ (Table 3). Event 20 was also separated at peak flow that resulted in higher proportions of event water in the forested catchment (35\%-43\%) than the mined catchment $(14 \%-26 \%)$ (Table 3). For the eight remaining events with complete records, streamflow was separated by only one method, by one isotope or in only one catchment. Hydrograph separations for these events mostly agreed with higher proportions of pre-event water, but the results are inconclusive given the large variability (Table 3). In many cases, we were not able to separate streamflow because: (1) the fraction of pre-event or event water was greater than total streamflow; (2) the poor performance (NSE $<0.50$ ) of runoff and/or tracer models; and/or (3) event water isotopic signatures were not distinguishable in sequential samples of streamflow (example shown for deuterium, Figure 9). The incomplete records of the remaining 14 events were primarily attributed to failure of the automated rainfall and streamflow sampling systems due to fouling or power loss.
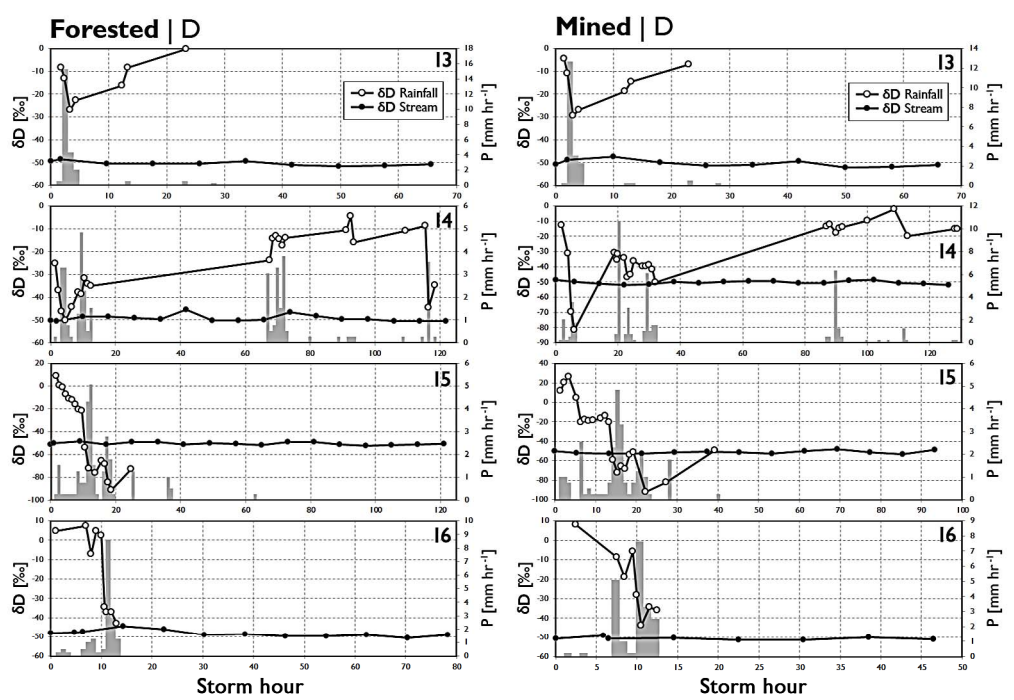

Figure 9. Plots of $\delta \mathrm{D}$ of rainfall and stream for selected events (13-16) for the mined and forested catchments. $\delta^{18} \mathrm{O}$ showed similar patterns for the same events. Rainfall in $\mathrm{mm} \mathrm{h}^{-1}$ shown in gray. Despite variations in rainfall isotopic compositions throughout storm events that in come cases crossed over, the stream isotopic composition showed little response to rainfall input, making hydrograph separation impossible for all but one event. 
Table 3. Storm event and pre-event water compositions based on isotope hydrograph separation using $\delta \mathrm{D}$ and $\delta^{18} \mathrm{O}$ in a traditional two-component mixing model and the transfer function hydrograph separation (TRANSEP) model. Of the 23 storm events measured in the study, only nine had complete isotope records, and only Event 20 was successfully separated into components, both isotopes and separation models. (-) indicates failure to separate the hydrograph, while the superscript indicates the source of error.

\begin{tabular}{|c|c|c|c|c|c|c|c|c|}
\hline \multirow{3}{*}{ Event } & \multicolumn{4}{|c|}{ Mined Catchment } & \multicolumn{4}{|c|}{ Forested Catchment } \\
\hline & \multicolumn{2}{|c|}{ Two-Component (\%/\%) } & \multicolumn{2}{|c|}{ TRANSEP (\%/\%) } & \multicolumn{2}{|c|}{ Two-Component (\%/\%) } & \multicolumn{2}{|c|}{ TRANSEP $(\% / \%)$} \\
\hline & $\delta \mathbf{D}$ & $\delta^{18} \mathrm{O}$ & $\delta \mathbf{D}$ & $\delta^{18} \mathrm{O}$ & $\delta \mathbf{D}$ & $\delta^{18} \mathrm{O}$ & $\delta \mathbf{D}$ & $\delta^{18} \mathrm{O}$ \\
\hline 2 & $39 / 61$ & $-a$ & $-b, c$ & $-b, c$ & $-a$ & $68 / 32$ & $-b, c$ & $-b, c$ \\
\hline 5 & $-a$ & $-a$ & $-b$ & $-b$ & $19 / 81$ & $-a$ & $-b$ & $-b$ \\
\hline 13 & $-a$ & $-a$ & $-b$ & $-b$ & - a & $-a$ & $-b$ & $-b$ \\
\hline 14 & $-{ }^{a}$ & $-{ }^{a}$ & $-b$ & $-b$ & $-{ }^{a}$ & $-a$ & $-b$ & $-b$ \\
\hline 15 & $-a$ & $-a$ & $-b$ & $-b$ & $-a$ & $-a$ & $-b$ & $-b$ \\
\hline 17 & $-a$ & $-a$ & $-b$ & $-b$ & $-a^{a}$ & $-a$ & $-b$ & $-b$ \\
\hline 20 & $21 / 79$ & $23 / 77$ & $21 / 79$ & $28 / 72$ & $24 / 76$ & $23 / 77$ & $23 / 77$ & $22 / 78$ \\
\hline${ }^{d}$ peak & $22 / 88$ & $17 / 83$ & $26 / 74$ & $23 / 77$ & $36 / 64$ & $36 / 64$ & $43 / 57$ & $35 / 65$ \\
\hline 21 & $6 / 94$ & $5 / 95$ & $-b$ & $-b$ & $27 / 73$ & $21 / 79$ & $-\mathrm{b}$ & $-b$ \\
\hline 23 & $-a$ & $30 / 70$ & $-b$ & $-b$ & $-b$ & $-\mathrm{b}$ & $16 / 84$ & $-b$ \\
\hline
\end{tabular}

${ }^{a}$ Fraction of preevent or event water greater than total streamflow. ${ }^{b}$ Poor $(\mathrm{NSE}<0.50)$ performance of event tracer model. ${ }^{c}$ Poor $(N S E<0.50)$ performance of preevent tracer model. ${ }^{d}$ Runoff separated at peak.

\section{Discussion}

\subsection{The Not-So-Clear Impacts of Mountaintop Removal Mining}

Despite significant differences in disturbance intensity between the two catchments, direct comparison and inference about the drivers of hydrologic change are complicated by scale differences [14] and potentially unaccounted for controls on catchment hydrology. While reconciling hydrologic responses across spatial scales remains an unresolved issue in hydrology [21], it is generally accepted that hydrologic responses are different between small and large watersheds [65]. Size disparity between the topographically-delineated contributing areas of the MTM-mined and forested catchment could explain hydrologic difference, since metrics, such as peak flow, quickflow, area-normalized streamflow and time-to-peak, tend to be negatively correlated with catchment size $[66,67]$. Based on subsurface recharge, the size of effective contributing areas is reversed. Hence, it could be expected that the hydrologic responses also differ. Given the large degree of uncertainty in the actual extent and connectivity of underground coal mines and coal seams, reanalysis of hydrometric, isotopic and response time modeling using the updated catchment areas was beyond the scope of the current study, but should be considered in future analyses.

While similarly-sized paired catchments could minimize hydrologic differences between a reference and a disturbed catchment [68], finding appropriate and accessible catchments in the region is nearly impossible given the long disturbance history, the mosaic of land cover, private property ownership and the ubiquity of surface and underground mining. A promising approach would be to examine the hydrology of a large number of catchments across scales and disturbance gradients instead of focusing on just two headwater catchments. Nevertheless, our study provides important insights into the complexity of catchment hydrology in the central Appalachian Mountains region that have important implications for flooding and water quality.

Given the propensity of surface mining to alter water balance components and flow paths (i.e., [69]), many of our results were expected and similar to previous studies. Despite similar event rainfall characteristics, the hydrology in the two catchments differed in significant ways; times-to-peak were shorter; hydrologic response times were faster; and total streamflow, peak flow, base flow and runoff ratios were greater in the mined catchment than the forested catchment. With $10 \%$ of the 
catchment actively being mined and completely devoid of vegetation at the time of our study and another $20 \%$ classified as grasses instead of native hardwood forests, greater streamflow (Figure 10) could plausibly be explained by water balance changes in ET from forest losses that exceed the $20 \%$ disturbance thresholds shown in the forest hydrology literature (e.g., [70,71]). Elevated base flow and flow duration downstream in the MTM-mined catchment are also consistent with previous studies that hypothesize that valley fills regulate runoff by temporarily storing and releasing water overtime $[2,24,31,32,72,73]$.

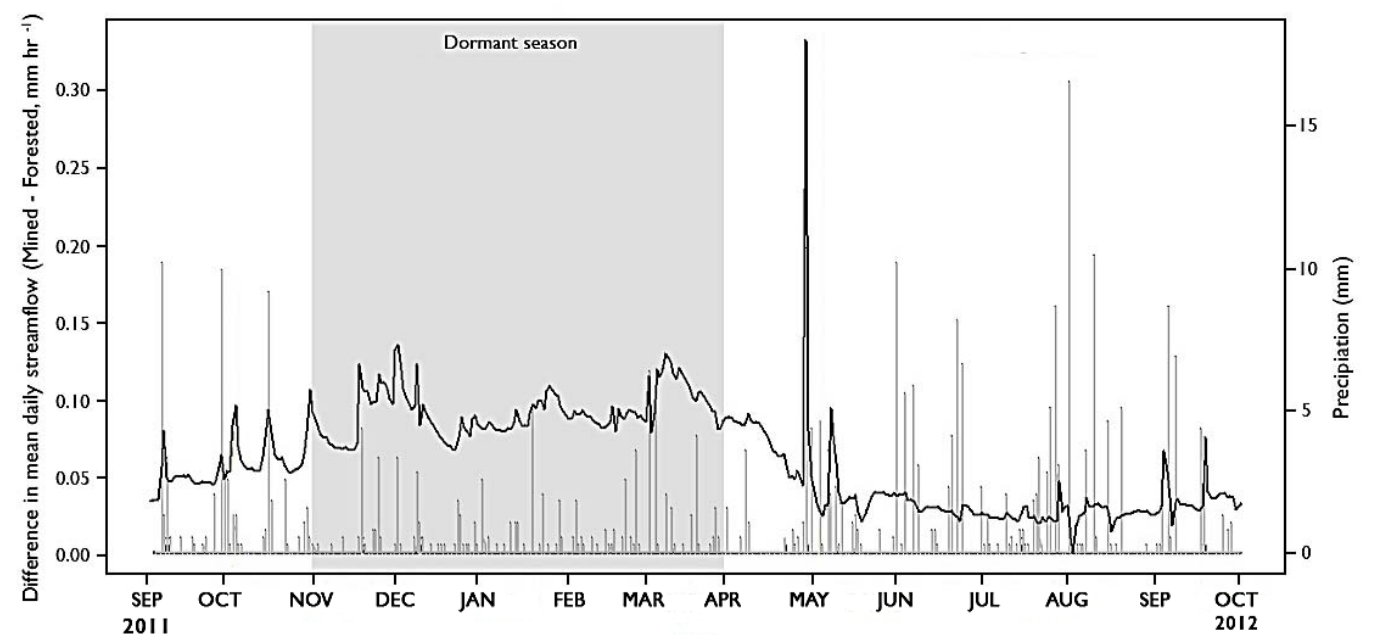

Figure 10. Runoff differences between the mined and forested catchment over the 13-month study period. The dormant season (November-April) is shaded. The greatest differences between catchments were during the dormant season, likely due to unaccounted for water from underground mine pools and inter-basin transfer.

However, our results and interpretation also differed in important ways, particularly with respect to the sources of more water; the unexpectedly smaller proportions of quickflow in the mined catchment; and the failure to separate runoff into event and pre-event components. While the streamflow and runoff ratio were significantly larger in the mined catchment, we do not believe that the larger volumes of water were solely attributed to reduced ET, but also to transient storage in valley fills and, potentially more important, water from abandoned underground coal mines and mine pools that underlie much of the catchment $[34,46]$. For changes in ET to be the dominant source of more water, we would expect the greatest differences between catchments during the growing season when plant water demand is highest. Instead, differences were greater during the dormant season when ET is minimal and antecedent soil moisture is highest.

\subsection{Uncertain Role Valley Fills and Underground Mines}

\subsubsection{Valley Fills}

The placement of fill material in headwater valleys substantially increases catchment storage over pre-disturbance conditions. Ross et al. [74] estimated that all of the valley fills located throughout the MTM region have a theoretical capacity to store $>1.3 \mathrm{~km}^{3}$ (or a depth of $7 \mathrm{~m}$ of water spread over the $180 \mathrm{~km}^{2}$ of land area occupied by valley fills) that is approximately equivalent to one year's worth of regional precipitation [74].

While increased catchment storage from valley fills has the clear effect of elevating streamflow, base flow and flow duration, its impact on storm flows in less well understood. Conceptually, valley fills should decrease storm flows by transiently storing and releasing runoff overtime (i.e., elevated 
flow duration), but some studies [5,24,73], including this one, observed larger peak flow downstream of valley fills. The paradox of elevated streamflow, base flow and peak flow downstream has been explored by [2], who conceptualized runoff generation in valley fills by the activation of preferential flow paths. During low flow conditions, runoff is dominated by steady-state matrix flow through torturous flow paths that sustain streamflow. During sufficiently-sized storms, the matrix and larger air-filled voids created by a large rock fragment within a valley fill become saturated, activating large preferential flow paths that could be responsible for large peak flows downstream.

\subsubsection{Underground Mines}

Groundwater flow directions in coal seams are primarily controlled by dip direction [35,75], and streams located down-dip and stratigraphically below coal seams can gain significant volumes of water [12]. Underground mines alter the subsurface structure [35] by creating large voids and subsidence fractures that increase hydraulic conductivity (e.g., $1.5 \mathrm{~m} \mathrm{~d}^{-1}$ [45]), as well as connectivity between the surface and subsurface and between water-bearing geologic units $[36,37,45]$. Rainfall can be rapidly translated to streamflow through near surface-stress relief fractures and underground mine pools that efficiently connect groundwater to surface streams [76]. This was observed in the nearby Elkhorn Creek watershed; dissolved oxygen, temperature and specific conductivity data collected at the outlet of a mined coal seam indicated rapid response to rainfall [45].

Large voids created by underground mining are major conduits for water movement and storage. Mine pools located below drainage often are completely flooded, where as mine pools located above drainage can be partially flooded or completely flooded during periods of high antecedent moisture and recharge. Connectivity to other mined and overlapping coal seams and proximity to perched aquifers also play important roles on the hydrologic condition and storage capacity of mine pools [46]. According to the West Virginia Mine Pool Atlas [46], mines pools in our study area are predominantly above drainage and partially flooded, but below drainage and completely flooded pools also exist. The maximum potential storage of partially-flooded and completely-flooded mine pools of the seven coal seams located in our study area totals $\sim 1 \mathrm{~km}^{3}$ [46], which, like valley fills, is approximately equivalent to mean annual rainfall for the region [74]. Hence, the transient storage potential of mine pools is vast and certainly plays a critical, albeit uncertain role in streamflow generation in our catchments.

Inter-basin transfer resulting from underground mining can move large volumes of water between catchments, further obfuscating dominant streamflow generation controls and hydrologic response to surface disturbance. Inter-basin transfer was an important source of streamflow in the aforementioned Elkhorn Creek watershed. Streamflow in two headwater catchments of Elkhorn Creek had anomalously large streamflow when compared to their topographic delineated drainage areas [45]. It was determined that nearly $2 \times$ and $9 \times$ larger drainage areas that extended $\sim 5 \mathrm{~km}$ beyond the topographic watershed divides were necessary to produce observed streamflow at the gauging stations. While detailed delineation of the underground recharge areas is beyond the scope of this study, the large number and estimated extent of up-dip underground mines below our catchments increases effective drainage areas by $2 \times$ or greater in the mined catchment and by as much as half in the forested catchment (Figure 3).

With streamflow in our study comprised of large contributions of water from unaccounted for water sources, isotope rainfall event signals would be indistinguishable in streamflow, making hydrograph separation impossible for all but one event. Why this one event was successful for both catchments was uncertain, but could be the result of similar pre-storm storage conditions of mine pools that resulted in similar proportions of pre-event water that dominated hydrographs. The general absence of isotopic variations in storm flow (Figure 9) in both catchments could be attributed to thorough mixing of rainfall with water from mine pools and by large recharge areas that incorporate water from up-dip underground mines that extend beyond the surface drainage area [45]. In a sense our failure to separate runoff into pre-event and event components using two-component mixing models 
supports this idea. Another possibility is the transfer of rainwater outside of our catchments through inter-basin transfer, but based on dip direction, we believe the former was more likely. More research is necessary to understand the significance of underground mine pools for runoff generation, particularly with respect to MTM-driven changes in hydrology.

Despite large uncertainties about the actual extents of effective recharge area, underground mine pools and inter-basin transfer likely play important roles in runoff generation, but how, and to what degree, remains uncertain. By simplifying catchment storage into a single reservoir $[56,77,78]$, waters originating from sources other than rainfall are not accounted for. Clearly, a two component mixing model is not appropriate for these systems. While geochemistry and multiple component mixing models could provide important insights into catchment processes, these sorts of detailed studies are complicated by restricted access [34], the ever-changing configuration of surface-mined catchments [11] and uncertainty in the extent and hydrologic conditions (partially or completely flooded) of mine pools [46].

\subsubsection{A Case for Threshold-Mediated Storm Responses}

The large variations in response curves early and later on during storms and the threshold behavior of storm flow in our catchments are consistent with threshold-mediated, connectivity-controlled runoff responses [79] that have been observed across different land forms, land cover and scales (e.g., $[80,81])$. While previous studies identified dominant roles of soil and hillslope storage on controlling runoff responses, we believe that streamflow in our catchments is primarily controlled by the filling, mixing and release of water from the transiently-connected and dynamic storage conditions of partially-flooded and completely-flooded mine pools. Our working hypothesis for streamflow generation in catchments that contain up-dip underground mine pools is that below-threshold storm responses likely reflect a mine pool storage threshold below which precipitation inputs mix with older water to recharge partially-flooded mine pools, and above which precipitation inputs activate a larger network of partially- to completely-flooded mine pools that results in non-linear storm flow responses with larger variability (Figure 7). This is not dissimilar to Miller and Zégre's [2] conceptualization of valley fill hydrology, although we believe underground mines play a more dominant role in streamflow generation in these catchments.

Threshold hydrologic responses in our study are consistent with findings from the Elkhorn Creek watershed study that showed a rapid response of mine discharge to precipitation despite the absence of variations in isotopic composition. It was determined that meteoric water of relatively recent origin (pre-event) derived from near surface-stress relief fractures and an older component of slow recharge of water from overlying perched aquifers and phreatic flow paths associated with stress relief, bedding plane and mining-induced fractures were dominant sources of recharge for streamflow in Elkhorn Creek [45]. Further, it was determined that recharge primarily occurred during warmer periods of the spring or fall, coincident with periods of high flow [45]. High streamflow in our catchments during the growing season (Figure 5) is consistent with seasonal recharge and could explain the larger variability and weaker correlation between precipitation and quickflow in the above-threshold storms that resulted from the activation of a large mine pool network beyond catchment boundaries.

\section{Implications and Conclusions}

MTM and underground mining significantly alter catchment hydrology by creating voids that increase catchment storage and runoff processes. The threshold behavior of runoff is likely the result of filling, mixing and releasing of water from partially- and completely-flooded mine pools and, to a lesser degree, valley fills. Fill and release cycles have important implications for water chemistry, since oxygen and water are unlimited under these conditions. The quality of water draining partially-flooded, above-drainage mines is often poorer for longer periods than completely flooded mines [76]. Unfortunately, water chemistry sampling and analysis was beyond the limits of this study and should be the focus of future work. 
Catchment hydrology in the Appalachian Coalfields region is complex, driven in part by obvious landscape-scale disturbances, such as mountaintop removal mining, but also by underground coal mining disturbance. The nearly two centuries of resource extraction has resulted in a mosaic of land covers, land uses and land forms that present significant challenges for determining baseline conditions and for understanding the extent and significance of MTM-driven impacts. The challenges for understanding the hydrological impacts of MTM are particularly evident given the paucity of catchment studies despite the nearly five decade-long use of this practice.

Nevertheless, our findings provide important insight into the complexity of catchment hydrology in this region and other areas with multiple, overlapping disturbances. Results suggest that underground mines likely are important controls for runoff generation in both obviously disturbed and seemingly undisturbed catchments having important implications for water chemistry and interact in uncertain ways with MTM-driven hydrological change. Future research should aim to isolate the respective impacts of MTM and underground mining to determine the nature of their interaction.

Acknowledgments: Funding for this research was provided by National Science Foundation Awards No. 1042683 and 1458952; the Oak Ridge Associated Universities (ORAU) Ralph E. Powe Junior Faculty Enhancement Award; the West Virginia University Faculty Senate Research Award R-14-025; and the Hatch Act Formula Funds. We are indebted to Bacon Brown for his support in this project. We thank Shannon Alex Shy for GIS support.

Author Contributions: Zégre conceived of and designed the experiments. Miller performed the experiments. Miller and Zégre analyzed the data and wrote the paper.

Conflicts of Interest: The authors declare no conflict of interest.

\section{References}

1. Ebel, B.A.; Mirus, B.B. Disturbance hydrology: Challenges and opportunities. Hydrol. Process. 2014, $28,5140-5148$.

2. Miller, A.; Zégre, N. Mountaintop removal mining and catchment hydrology. Water 2014, 6, 472-499.

3. Griffith, M.B.; Norton, S.B.; Alexander, L.C.; Pollard, A.I.; LeDuc, S.D. The effects of mountaintop mines and valley fills on the physicochemical quality of stream ecosystems in the central Appalachians: A review. Sci. Total Environ. 2012, 417-418, 1-12.

4. Merriam, E.R.; Petty, J.T.; Strager, M.P.; Maxwell, A.E.; Ziemkiewicz, P.F. Landscape-based cumulative effects models for predicting stream response to mountaintop mining in multistressor Appalachian watersheds. Freshw. Sci. 2015, 34, 1006-1019.

5. Wiley, J.B.; Brogan, F.D. Comparison of Peak Discharges Among Sites With and Without Valley Fills for the 8-9 July 2001, Flood in the Headwaters of Clear Fork, Coal River Basin, Mountaintop Coal-Mining Region, Southern West Virginia; Technical Report 03-133; U.S. Geological Survey: Reston, VA, USA, 2003.

6. Lindberg, T.T.; Bernhardt, E.S.; Bier, R.; Helton, A.M.; Merola, R.B.; Vengosh, A.; Di Giulio, R.T. Cumulative impacts of mountaintop mining on an Appalachian watershed. Proc. Natl. Acad. Sci. USA 2011, 108, 20929-20934.

7. Bernhardt, E.S.; Lutz, B.D.; King, R.S.; Fay, J.P.; Carter, C.E.; Helton, A.M.; Campagna, D.; Amos, J. How many mountains can we mine? Assessing the regional degradation of central Appalachian rivers by surface coal mining. Environ. Sci. Technol. 2012, 46, 8115-8122.

8. Saylor, K.L. Land Cover Trends: Central Appalachians; U.S. Geological Survey: Reston, VA, USA, 2008.

9. Townsend, P.A.; Helmers, D.P.; Kingdon, C.C.; McNeil, B.E.; Beurs, K.M.D.; Eshleman, K.N. Changes in the extent of surface mining and reclamation in the Central Appalachians detected using a 1976-2006 Landsat time series. Remote Sens. Environ. 2009, 113, 62-72.

10. EPA. The Effects of Mountaintop Mines and Valley Fills on Aquatic Ecosystems of the Central Appalachian Coalfield; Technical Report EPA/600/R-09/138F; US Environmental Protection Agency: Washington, DC, USA, 2011.

11. Bonta, J. Challenges in conducting hydrologic and water quality research in drastically disturbed watersheds. J. Soil Water Conserv. 2005, 60, 121-133.

12. Borchers, J.; Ehlke, T.; Mathes, M.; Downs, S. The Effects of Coal Mining on the Hydrologic Environmnet of Selected Stream Basins in Southern West Virginia; U.S. Geological Survey: Reston, VA, USA, 1991. 
13. McCormick, B.C.; Eshleman, K.N.; Griffith, J.L.; Townsend, P.A. Detection of flooding responses at the river basin scale enhanced by land use change. Water Resour. Res. 2009, 45, doi:10.1029/2008WR007594.

14. Negley, T.L.; Eshleman, K.N. Comparison of stormflow responses of surface-mined and forested watersheds in the Appalachian Mountains, USA. Hydrol.Process. 2006, 20, doi: 10.1002/hyp.6148.

15. Phillips, J.D. Impacts of surface mine valley fills on headwater floods in eastern Kentucky. Environ. Geol. 2004, doi 10.2007/s00254-003-0883-1.

16. Keene, T.; Skousen, J. Mine spoil reclamation with switchgrass for biofuel production. In Proceedings of the 2010 National Meeting of the American Society of Mining and Reclamation, Pittsburgh, PA, USA, 5-11 June 2010.

17. Peng, S.S. Mountaintop removal controversy slows West Virginia Coal Mining. Min. Eng. 2000, 52, 53-58.

18. Hartman, K.; Kaller, M.; Howell, J.; Sweka, J. How much do valley fills influence headwater streams? Hydrobiologia 2005, 532, 91-102.

19. Merriam, E.R.; Petty, J.T.; Merovich, G.T.; Fulton, J.B.; Strager, M.P. Additive effects of mining and residential development on stream conditions in a central Appalachian watershed. J. N. Am. Benthol. Soc. 2011, 30, 399-418.

20. McGuire, K.J.; McDonnell, J.J. Hydrological connectivity of hillslopes and streams: Characteristic time scales and nonlinearities. Water Resour. Res. 2010, 46, W10543, doi:10.1029/2010WR009341.

21. McGlynn, B.; McDonnell, J.; Seibert, J.; Kendall, C. Scale effects on headwater catchment runoff timing, flow sources, and groundwater-streamflow relations. Water Resour. Res. 2004, 40, doi:10.1029/2003WR002494.

22. Zipper, C.; Burger, J.; Skousen, J.; Angel, P.; Barton, C.; Davis, V.; Franklin, J. Restoring forests and associated ecosystem services on Appalachian coal surface mines. Environ. Manag. 2011, 47, 751-765.

23. Taylor, T.J.; Agouridis, C.T.; Warner, R.C.; Barton, C.D.; Angel, P.N. Hydrologic characteristics of Appalachian loose-dumped spoil in the Cumberland Plateau of eastern Kentucky. Hydrol. Process. 2009, 23, doi:10.1002/hyp.7443.

24. Messinger, T. Comparison of Storm Response of Streams in Small, Unmined and Valley-Filled Watersheds, 1999-2001, Ballard Fork, West Virginia; Technical Report 02-4303; USGS: Reston, VA, USA, 2003.

25. Bussler, B.H.; Byrnes, W.R.; Pope, P.E.; Chaney, W.R. Properties of minesoil reclaimed for forest land use. Soil Sci. Soc. Am. J. 1984, 48, 178-184.

26. Guebert, M.D.; Gardner, T.W. Macropore flow on a reclaimed surface mine: Infiltration and hillslope hydrology. Geomorphology 2001, 39, 151-169.

27. Chong, S.K.; Cowsert, P.T. Infiltration in reclaimed mined land ameliorated with deep tillage treatments . Soil Tillage Res. 1997, 44, 255-264.

28. Bonta, J.V.; Amerman, C.R.; Harlukowicz, T.J.; Dick, W.A. Impact of coal-surface mining on three Ohio watersheds - surface-water hydrology. J. Am. Water Resour. Assoc. 1997, 33, 907-917.

29. Ferrari, J.R.; Lookingbill, T.R.; McCormick, B.; Townsend, P.A.; Eshleman, K.N. Surface mining and reclamation effects on flood response of watersheds in the central Appalachian Plateau region. Water Resour. Res. 2009, 45, doi:10.1029/2008WR007109.

30. Dickens, P.S.; Minear, R.A.; Tschantz, B.A. Hydrologic alteration of mountain watersheds from surface mining. J. Water Pollut. Control Fed. 1989, 61, 1249-1260.

31. Wiley, J.B.; Evaldi, R.D.; Eychaner, J.H.; Chambers, D.B. Reconnaissance of Stream Geomorphology, Low Streamflow, and Stream Temperature in the Mountaintop Coal-Mining Region, Southern West Virginia, 1999-2000 ; U.S. Geological Survey: Reston, VA, USA, 2001.

32. Green, J.; Passmore, M.; Childers, H. A Survey of the Condition of Streams in the Primary Region Of Mountaintop Mining/Valley Fill Coal Mining; US EPA: Washington, DC, USA, 2000.

33. Zégre, N.P.; Maxwell, A.; Lamont, S. Characterizing streamflow response of a mountaintop-mined watershed to changing land use. Appl. Geogr. 2013, 39, 5-15.

34. Zégre, N.P.; Miller, A.J.; Maxwell, A.; Lamont, S.J. Multiscale analysis of hydrology in a mountaintop mine-impacted watershed. JAWRA J. Am. Water Resour. Assoc. 2014, 50, 1257-1272.

35. Puente, C.; Atkins, J.T. Simulation of Rainfall-Runoff Response in Mined and Unmined Watersheds in Coal Areas of West Virginia; Technical Report Water Supply Paper 2298; US Geological Survey: Reston, VA, USA, 1989.

36. Hobba, W.J. Effects of Underground Mining and Mine Collapse on the Hydrology Of Selected Basins in West Virginia; Technical Report 4900012; US Geological Survey: Reston, VA, USA, 1981. 
37. Hawkins, J.W.; Dunn, M. Hydrologic characteristics of a 35-year-old underground mine pool. Mine Water Environ. 2007, 26, 150-159.

38. Cardwell, D.; Erwin, R.; Woodward, H. Geologic Map of West Virginia; 1:250,000. West Virginia Geological and Economic Survey: Morgantown, WV, USA, 1968.

39. Ehlke, T.; Runner, G.; Downs, S. Hydrology of Area 9, Eastern Coal Province, West Virginia; Open-File Report 81-803; US Geological Survey: Reston, VA, USA, 1982.

40. Adams, M.B.; Edwards, P.J.; Ford, W.M.; Schuler, T.M.; Thomas-Van Gundy, M.; Wood, F. Fernow Experimental Forest: Research History and Opportunities; USDA Forest Service: Washington, DC, USA, 2012.

41. Kipp, J.A.; Dinger, J.S. Stress-relief fracture control of ground-water movement in the Appalachian plateaus. In Proceedings of the Fourth Annual Eastern Regional Groun Water Conference, Burlington, VT, USA, 14-16 July 1987; pp. 423-438.

42. Wyrick, G.G.; Borchers, J.W. Hydrologic Effects of Stress-Relief Fracturing in an Appalachian Valley [West Virginia]; US Geological Survey: Reston, VA, USA, 1981.

43. Smith, J.A.; Baeck, M.L.; Ntelekos, A.A.; Villarini, G.; Steiner, M. Extreme rainfall and flooding from orographic thunderstorms in the central Appalachians. Water Resour. Res. 2011, 47, W04514, doi:10.1029/2010WR010190.

44. US Congress. Surface Mine Control and Reclamation Act; US Congress: Washington, DC, USA, 1977.

45. Kozar, M.D.; McCoy, K.J.; Britton, J.Q.; Bascombe M. Blake, J. Hydrogeology, Groundwater Flow, and Groundwater Quality of an Abandoned Underground Coal-Mine Aquifer, Elkhorn Area, West Virginia; Technical Report Bulletin B-46; USGS: Reston, VA, USA, 2012.

46. McColloch, J.S.; Richard D. Binns, J.; Bascombe M. Blake, J.; Clifford, M.T.; Gooding, S.E. West Virginia Mine Pool Atlas; Technical Report 036; West Virginia Department of Environmental Protection: Charleston, WV, USA, 2012.

47. Turnipseed, D.; Sauer, V. Discharge Measurements at Gaging Stations; U.S. Geological Survey: Reston, VA, USA, 2010.

48. Hudson, R.; Fraser, J. Introduction to Salt Dilution Gauging for Streamflow Measurement Part IV: The Mass Balance (or Dry Injection) Method. Streamline 2005, 9, 1-7.

49. Hewlett, J.D.; Hibbert, A.R. Factors Affecting The Response Of Small Watersheds To Precipitation in Humid Areas; Pergamon Press: Oxford, UK, 1967.

50. Jakeman, A.J.; Hornberger, G.M. How much complexity is warranted in a rainfall-runoff model? Water Resour. Res. 1993, 29, 2637-2649.

51. Nippgen, F.; McGlynn, B.L.; Marshall, L.A.; Emanuel, R.E. Landscape structure and climate influences on hydrologic response. Water Resour. Res. 2011, 47, W12528, doi:10.1029/2011WR011161.

52. Heathcote, J.A.; Lloyd, J.W. Factors affecting the isotopic composition of daily rainfall at Driby, Lincolnshire. J. Climatol. 1986, 6, 97-106.

53. Matsuo, S.; Friedman, I. Deuterium content in fractionally collected rainwater. J. Geophys. Res. 1967, 72, 6374-6376.

54. McDonnell, J.J.; Bonell, M.; Stewart, M.K.; Pearce, A.J. Deuterium variations in storm rainfall: Implications for stream hydrograph separation. Water Resour. Res. 1990, 26, 455-458.

55. Craig, H. Isotopic variations in meteoric waters. Science 1961, 133, 1702-1703.

56. Sklash, M.G.; Farvolden, R.N. The role of groundwater in storm runoff . J. Hydrol. 1979, 43, 45-65.

57. Buttle, J. Isotope hydrograph separations and rapid delivery of pre-event water from drainage basins. Prog. Phys. Geogr. 1994, 18, 16-41.

58. Weiler, M.; McGlynn, B.L.; McGuire, K.J.; McDonnell, J.J. How does rainfall become runoff? A combined tracer and runoff transfer function approach. Water Resour. Res. 2003, 39, doi:10.1029/2003WR002331.

59. Roa-García, M.C.; Weiler, M. Integrated response and transit time distributions of watersheds by combining hydrograph separation and long-term transit time modeling. Hydrol. Earth Syst. Sci. 2010, 14, 1537-1549.

60. Lyon, S.W.; Desilets, S.L.E.; Troch, P.A. Characterizing the response of a catchment to an extreme rainfall event using hydrometric and isotopic data. Water Resour. Res. 2008, 44, W06413, doi:10.1029/2007WR006259.

61. McGuire, K.J.; McDonnell, J.J.; Weiler, M.; Kendall, C.; McGlynn, B.L.; Welker, J.M.; Seibert, J. The role of topography on catchment-scale water residence time. Water Resour. Res. 2005, 41, doi:10.1029/2004WR003657. 
62. Abbaspour, K.C.; Schulin, R.; van Genuchten, M.T. Estimating unsaturated soil hydraulic parameters using ant colony optimization. Adv. Water Resour. 2001, 24, 827-841.

63. Nash, J.; Sutcliffe, J. River flow forecasting through conceptual models. Part I: A discussion of principles. J. Hydrol. 1970, 10, 282-290.

64. Beven, K. Parameter Estimation and Predictive Uncertainty. In Rainfall-Runoff Modelling: The Primer; John Wiley and Sons, Ltd.: Chichester, UK, 2001.

65. Pilgrim, D.H.; Cordery, I.; Baron, B.C. Effects of catchment size on runoff relationships. J. Hydrol. 1982, 58, 205-221.

66. Heerdegen, R.G.; Reich, B.M. Unit hydrographs for catchments of different sizes and dissimilar regions. J. Hydrol. 1974, 22, 143-153.

67. Post, D.A.; Jakeman, A.J. Relationships between catchment attributes and hydrological response characteristics in small Australian mountain ash catchments. Hydrol. Process. 1996, 10, 877-892.

68. Hewlett, J.D.; Pienaar, L. Design and analysis of the catchment experiment. In Proceedings of the Symposium on Use of Small Watersheds in Determining Effects of Forest Land Use on Water Quality, Lexington, KY, USA, 22-23 May 1973.

69. Ritter, J.B.; Gardner, T.W. Hydrologic evolution of drainage basins disturbed by surface mining, central Pennsylvania. GSA Bull. 1993, 105, 101-115.

70. Bosch, J.M.; Hewlett, J.D. A review of catchment experiments to determine the effect of vegetation changes on water yield and evapotranspiration. J. Hydrol. 1982, 55, 3-23.

71. Stednick, J.D. Monitoring the effects of timber harvest on annual water yield. J. Hydrol. 1996, 176, 79-95.

72. Paybins, K.S. Flow Origin, Drainage Area, and Hydrologic Characteristics for Headwater Streams in the Mountaintop Coal-Mining Region of Southern West Virginia, 2000-01; Water-Resources Investigations Report 02-4300; U.S. Geological Survey: Reston, VA, USA, 2003.

73. Messinger, T.; Paybins, K. Relations between Precipitation and Daily and Monthly Mean Flows in Gaged, Unmined and Valley-Filled Watersheds, Ballard Fork, West Virginia, 1999-2001; Technical Report WRi no.2003-4113; USGS: Reston, VA, USA, 2003.

74. Ross, M.R.V.; McGlynn, B.L.; Bernhardt, E.S. Deep impact: Effects of mountaintop mining on surface topography, bedrock structure, and downstream waters. Environ. Sci. Technol. 2016, 50, 2064-2074.

75. Rozell, D.J.; Reaven, S.J. Water pollution risk associated with natural gas extraction from the marcellus shale. Risk Anal. 2012, 32, 1382-1393.

76. Demchak, J.; Skousen, J.; McDonald, L.M. Longevity of acid discharges from underground mines located above the regional water table. J. Environ. Qual. 2004, 33, 656-668.

77. Sklash, M.G., Environmental isotope studies of storm and snowmelt runoff generation. In Process Studies in Hillslope Hydrology; Anderson, M.G., Burt, T.P., Eds.; John Wiley and Sons: Chichester, UK, 1990; pp. 401-435.

78. Sklash, M.G.; Farvolden, R.N. The use of environmental isotopes in the study of high-runoff episodes in streams. In Isotope Studies of Hydrologic Processes; Perry, E.C., Jr., Montgomery, C.W., Eds.; Northern Illinois University Press: Dekald, IL, USA, 1982; pp. 65-73.

79. Spence, C. A paradigm shift in hydrology: Storage thresholds across scales influence catchment runoff generation. Geogr. Compass 2010, 4, 819-833.

80. Tromp-vanMeerveld, H.J.; McDonnell, J.J. Threshold relations in subsurface stormflow: 2. The fill and spill hypothesis. Water Resour. Res. 2006, 42, doi:10.1029/2004WR003800.

81. Detty, J.M.; McGuire, K.J. Threshold changes in storm runoff generation at a till-mantled headwater catchment. Water Resour. Res. 2010, 46, doi:10.1029/2009WR008102.

(C) 2016 by the authors; licensee MDPI, Basel, Switzerland. This article is an open access article distributed under the terms and conditions of the Creative Commons Attribution (CC-BY) license (http:/ / creativecommons.org/licenses/by/4.0/). 